\title{
New insights on the environmental Kuznets curve hypothesis in developing and transition economies. A literature survey
}

\author{
Alexandra-Anca PURCEL* \\ Babeș-Bolyai University, Faculty of Economics and Business Administration, Teodor Mihali St. \\ 58-60 400591, Cluj-Napoca, Romania \\ Université Clermont Auvergne, CNRS, IRD, CERDI, F-63000 Clermont-Ferrand, France
}

*Corresponding author: alexandra.anca.p@gmail.com

\begin{abstract}
We perform an updated literature survey on pollution-growth nexus via the Environmental Kuznets Curve (EKC) hypothesis, both from theoretical and empirical standpoints. First, we conduct a literature review on the most well-known rationale behind the EKC prevalence and discuss the key components of the research design when estimating the EKC. Second, we bring together the most influential empirical papers published in the last decade, which focus on EKC estimation in developing and transition economies. Overall, succeeding to curtail some of the deficiencies suggested by theoretical contributions, the recent empirical studies might indicate a certain consensus regarding pollution-growth nexus, and EKC validity. On the one hand, reinforcing the EKC nature, several studies reveal a long-run relationship between indicators. On the other hand, according to income coefficients signs, the traditional bell-shape pattern seems to be at work for some developing and transition economies. However, in some cases, the estimated turning point lies outside the income sample range, calling into question not only the true pattern between pollution and growth but also the identification of EKC. Taken collectively, both the theoretical foundations and empirical evidence, could contribute to a better understanding of the pollution-growth nexus in the EKC context, and suggest some useful insights regarding the future works on the subject as well as the crucial policy implications in this group of countries.
\end{abstract}

Keywords: environmental Kuznets curve hypothesis; developing and transition economies; literature survey.

JEL Classification: Q53, Q56, Q43.

Acknowledgments: I am indebted to the Editor (Shunsuke Managi), three anonymous referees, and Dorina Lazăr and Alexandru Minea for very constructive comments and suggestions that improved the manuscript significantly. I also gratefully acknowledge the support from the French Embassy and the French Institute in Romania. All remaining errors are mine. Usual disclaimers apply. 


\section{Introduction}

Recently, one of the major concerns of nations has become global warming, and particularly the adverse effects that this phenomenon produces on Earth and implicitly on the quality of life. Along with the start of the Industrial Revolution, there are significant changes at the global level, both economically and socially, which also reflects on the environment.

As an answer to the concerns related to environmental degradation-economic growth nexus, and the desire to synthesize them into a general mission of the population and the competent bodies, the World Commission on Environment and Development (1987) in the report entitled Our Common Future (i.e. Brundtland Report), shaped the definition of sustainable development. According to this publication, "sustainable development is development that meets the needs of the present without compromising the ability of future generations to meet their own needs" (United Nations General Assembly, 1987, p. 41) ${ }^{1}$. Indeed, this may not be the first and the perfect attempt to define what sustainable development constitutes, but we surely can argue that is one of the most used and debated explanation in the related literature (see e.g. Seghezzo, 2009; Ciegis et al., 2009; Stoddart, 2011; Holden et al. 2014, among others). Furthermore, if we look back in history, before the Brundtland report, Malthus (1798), in his book "Essay on the Principle of Population" outlines some important future changing in nations' economic structure. He argues that the world's population grows at a geometric rate while the food supply increases at an arithmetic rate, leading over time to exhaustion of natural resources. Later, a report writes by Meadows et al. (1972), and suggestively named "The Limits to Growth" brings to light the same issues related to the excessive increases in population and economy due to industrial expansion, while natural resources follow a downward trend. Authors such as Basiago (1999) and Sandmo (2015) highlight the importance of these two studies as fundamental pillars in the development of environmental and energy economics as an autonomous field.

Consequently, the importance of awareness of environmental protection and its interdependence with specific indicators at the macro- and micro-economic level have become an important topic in the early literature. Besides, along with the development of new theoretical concepts, more and more empirical studies have begun to emerge. Nowadays, as a result of the

\footnotetext{
${ }^{1}$ https://sustainabledevelopment.un.org/content/documents/5987our-common-future.pdf
} 
increase in data availability and the development of more sophisticated statistical techniques, there is a substantial flow of research papers related to the field of environmental and energy economics.

This study aims to review in an integrated framework the key theoretical aspects and give an updated empirical overview of the relationship between environmental degradation and economic growth via the Environmental Kuznets Curve (hereafter EKC) hypothesis. In doing so, first, we tackle the theoretical knowledge regarding the EKC, by stating the most well-known rationales behind its prevalence. Next, we move across towards the research design in terms of EKC testing and provide some details about its fundamental components, namely the model specification, assumptions, econometric methodology, and identification strategy. Second, we survey the empirical papers published in the last decade (i.e. from 2010 to 2019) that focus on developing $^{2}$ and transition economies and investigate the validity of the EKC hypothesis. Therefore, comprising together the latest published research, we would have a more homogeneous picture of the EKC literature. Moreover, along with the rapid development of more advanced statistical techniques and the increase in data availability and quality, the EKC testing approaches have also changed (Dasgupta et al., 2002; Lieb, 2003). As such, we are inclined to believe that, on the one hand, the recent studies are more accurate vis-à-vis the research design, while, on the other hand, the increased data quality has improved the prediction of EKC both in terms of parameters and turning point estimates. Relying on this intuition, and opposite with the review of He (2007), who targets the SO2 EKC hypothesis for the developing and transition economies and Shahbaz and Sinha (2019), who concentrate on the CO2 EKC hypothesis, we survey the papers independent of pollution indicator used in EKC testing. Also, compared to the survey of Tiba and Omri (2017) on the relationship between energy, environment, and growth, we focus solely on the EKC hypothesis works and provide an updated review of the related literature.

Our findings are as follows. First, several studies reveal a long-term relationship between environmental pollution and income. Thus, the long-run character of EKC seems to prevail and strengthen the belief that the EKC is rather a phenomenon that may be observed over a relatively long period, all the more that the effects of environmental policy are visible after years from implementation. Second, it is encouraging to see that the bell-shape pattern between pollution and growth seems to emerge frequently for some developing and transition states-perhaps contrary to the general intuition that it is more challenging for these countries, compared to developed ones,

\footnotetext{
${ }^{2}$ In this paper, the term "developing" refers to both developing and emerging economies.
} 
to reach the optimal level of growth that could ensure the decline of pollution level, i.e. inducing an upward bending curve. Overall, this may suggest that less-developed nations might improve their environmental quality by avoiding and learning from the mistakes made by developed countries, and even switch pollution trends in favor of the environment for a lower income level (Munasinghe, 1999; Dinda, 2004; Yao et al., 2019). However, the mixed results are expected when spanning different periods and using different pollution indicators, even for the same country or group of countries. Third, in some cases, the estimated turning point lies outside the income sample values. As such, this may imply, on the one hand, a possible monotonically increasing pattern between indicators (see e.g. Cole et al., 1997; Stern and Common, 2001; Lieb, 2003) and, on the other hand, might reveal potential weaknesses in the identification of EKC (see e.g. Bernard et al., 2014). Regarding the latter, it becomes imperative for the researcher to determine the minimum set of assumptions to identify the genuine causal effects between variables and if we refer to the parametric approach to identify the parameters point estimate. Also, a broader perspective in terms of the statistical methods may provide further insights into EKC and narrow some of the related uncertainties. In this fashion, the methods designed to minimize the model assumptions, such as semi-, and non-parametric techniques ${ }^{3}$, along with the ones that go beyond the time-domain approach, such as wavelet techniques related to the time-frequency domain, may provide a sound basis of comparison for the traditional econometric tools, or vice-versa (i.e. parametric methods should be seen as complementary to these methods). Ultimately, a valuable alternative to achieve robustness is when the results of different techniques incline, more or less, towards the same conclusion. For example, based on our short nonparametric descriptive exercise, China exhibits an increasing pattern between CO2 and GDP, a result also suggested by several time-series and panel studies included in our empirical review — although the sign of the associated income coefficients indicate a bell-shape pattern, some studies find turning points that lie outside the income sample range, thus, indicating a positive relationship ${ }^{4}$.

The rest of the paper is organized as follows. Section 2 discusses the theoretical arguments that constitute the basis of the bell-shaped pattern between pollution and economic growth, Section

\footnotetext{
${ }^{3}$ It is worth mentioning that we do not argue that this type of analysis should be performed instead of a parametric one, or provide better results at the advantage of fewer assumptions.

${ }^{4}$ We take China as an example since a large number of studies considered focus on testing EKC for this country, compared to other states. However, a comparison could be made for the other states as well. Besides, we look for an overall behavior independent of the period analyzed, pollution indicator, and empirical methodology.
} 
3 explores the potential patterns between $\mathrm{CO} 2$ emissions and economic growth descriptively, Section 4 reviews the empirical studies on EKC, and Section 5 concludes and provide some policy implications.

\section{Theoretical aspects of EKC}

Presumably, one of the most tested hypotheses in the literature that stresses the relationship between environmental degradation and economic growth is the EKC hypothesis. The assumption that the link between pollution and economic growth follows a bell-shape pattern is first introduced in the literature by Grossman and Krueger (1991). In their seminal paper, the authors analyze the implications that the North American Free Trade Agreement (NAFTA) has on the environment through the medium of economic growth. Based on the empirical findings, they conclude that the form of the relationship between economic growth and environmental degradation is inverted Ushaped. Thus, the quality of the environment tends to deteriorate along with economic growth until an income threshold is reached, from which the trend is reversed in favor of the environment. Approximately during the same period, Shafik and Bandyopadhyay (1992) and Panayotou (1993) also search into the implications of economic growth on the environment, while the latter named the relationship between these two macro-indicators the EKC.

\subsection{The rationale behind the EKC hypothesis}

Throughout the years, the number of studies that have approached both theoretically and empirically the EKC hypothesis and its extensions have increased considerably. Most researchers have tried to answer the following question: Which are the drivers that shape the relationship between environmental degradation and economic development? Some authors provide potential explanations based on economic intuition. In contrast, others develop well-grounded theoretical models around a series of assumptions and/or restrictions which at least theoretically generate a bell-shaped pattern between pollution and economic growth. In the following, we look at some well-known rationale behind the EKC hypothesis provided by the existing literature, from both the side of economic intuition and theory, and briefly discuss them.

First, Grossman and Krueger (1991) argue that the scale, structural, and technological effect may explain the nexus between pollution and growth. The scale effect manifests as a result 
of economic activity expanse, which in turn induces a rise in the pollution levels. In contrast, structural or compositional effect accounts for the structural changes that take place within the economy. Furthermore, once nations attain industrial apogee, they focus more on the development of information-based industries and services. Thus, as a state becomes intensive in services, it ensures a higher economic growth rate, and eventually, a steady decline in environmental degradation. Besides, in the post-industrial phase, countries have the necessary resources to invest in research, development, and innovation programs, and due to technological advancement, old technologies are gradually replaced with more efficient and less polluting ones (Panayotou, 1993, 2003).

Second, the nation's economic development also implies an increase in the population income. As such, if the quality of the environment is regarded as a normal good, its demand may be influenced positively. In the related literature, some researchers have empirically confirmed the presumption that environmental quality is a normal good (see e.g. Kristrom and Riera, 1996; Bruneau and Echevarria, 2009; Martini and Tiezzi, 2014), while researchers such as Pearce and Palmer (2005) and Ghalwash (2007) have argued that the quality of the environment is more a luxury good. Consequently, the soundness of the EKC hypothesis may be a consequence of these fluctuations in the income elasticity of demand for environmental improvement.

Third, along with the rise in income, the individual's perception of the adverse effects of environmental degradation on quality of life also increases. As an overall outcome, compared to poorer countries, developed states tend to adopt more stringent environmental policies and regulations. Hence, in developing states, environmental regulations are fewer, and they are prone to become pollution havens for dirty industries that migrate from developed ones (Lucas et al., 1992). Also, authors such as Stern et al. (1996), Suri and Chapman (1998), and Stern (2003), among others, advocate that the bell-shaped pattern for developed nations may be explained through the implications of trade. Moreover, researchers such as Dasgupta et al. (2002), among others, argue that improvements in environmental quality are possible even in developing countries. Besides, the pollution may follow a downward trend for a lower level of income than those experienced by developed countries, considering the increase in the availability and novelty of methods to combat pollution.

Fourth, in the early literature, some authors provide theoretical models that attempt to explain the EKC behavior. In this fashion, some of these early theoretical works are discussed in 
the well-know study of Stern (2004). Likewise, more recently, Kijima et al. (2010) provide a comprehensive and valuable survey on both theoretical static and dynamic models behind the EKC hypothesis with detailed mathematical explanations, along with a review on empirical analysis. In Table 1, we summarize these theoretical contributions concerning the EKC hypothesis as they appear in Kijima et al. (2010).

Table 1. Theoretical studies on EKC based on Kijima et al. (2010)

\begin{tabular}{|c|c|}
\hline \multicolumn{2}{|c|}{ Static models } \\
\hline Model type & Authors \\
\hline Models with macroeconomic production functions & Lopez (1994), Lopez and Mitra (2000). \\
\hline Models with utility functions only & $\begin{array}{l}\text { McConnell (1997), Andreoni and Levinson (2001), Lieb } \\
\text { (2002), Di Vita (2004). }\end{array}$ \\
\hline \multicolumn{2}{|c|}{ Dynamic models } \\
\hline Resource allocation & $\begin{array}{l}\text { John and Pecchenino (1994), John et al. (1995), Selden } \\
\text { and Song (1995), Lieb (2004), Dinda (2005), Chimeli } \\
\text { and Braden (2008), Prieur (2009). }\end{array}$ \\
\hline Technology and resource selection & $\begin{array}{l}\text { Stokey (1998), Hartman and Kwon (2005), Tahvonen } \\
\text { and Salo (2001). }\end{array}$ \\
\hline Tax policy & Jones and Manuelli (2001), Egli and Steger (2007). \\
\hline Real options approach & Wirl (2006), Kijima et al. (2011). \\
\hline
\end{tabular}

In addition to this theoretical works, Brock and Taylor (2010) taking stock of the earlier theory literature (e.g. Stokey, 1998), establish the EKC hypothesis-Solow model nexus. In their seminal contribution, the authors use the underlying assumptions of the well-known neoclassical growth model introduced by Solow (1956) and account for environmental pollution in the main equation of the Cobb-Douglas production function. As such, they developed a new model (i.e. Green Solow model) which provide a theoretical setup that may explain the bell-shaped pattern between pollution and economic growth through the same forces that assure the course of economic growth, namely the law of diminishing returns and the advancement of new technology (Brock and Taylor, 2010). Subsequently, as Kijima et al. (2010) argue, the Green Solow model is "a macroeconomic dynamic model in which total production is allocated to consumption and abatement expenditure" (Kijima et al., 2010, p. 1193). Indeed, the Green Solow model is a simple dynamic model that may give a strong rationale behind the EKC hypothesis, and an adapted empirically testable convergence equation for emissions per capita.

Conversely, Ordás Carido et al. (2011) further develop the Green Solow model and provide a theoretical framework in which the reduction in pollution is endogenously determined. In particular, the theoretical predictions formulated by authors suggest that through the scale (defensive) effect, the growth rates in pollution are associated positively (negatively) with GDP 
growth (emissions levels). Next, using convergence-type equations estimated based on three different econometric approaches (i.e. parametric, semi-, and non-parametric), the authors show that the data validate both the scale and defensive effect. Besides, the possible reverse causality between pollution and growth implied by the theoretical model is addressed empirically by employing instrumental variables. Overall, the empirical findings suggest that the more flexible specifications (semi-, and non-parametric) are preferred when modeling the data, compared with the classical parametric ones. Moreover, opposed to Brock and Taylor (2010), who link CO2 emissions (a global stock pollutant) with economic growth, the theoretical model introduced in Ordás Carido et al. (2011) is designed for local flow pollutants, such as SO2 and NOx emissions.

In this sub-section, we review some notable empirical and theoretical works that target the pollution-growth nexus and seek directly, or at least indirectly, into the rationale that may explain the bell-shaped pattern between the indicators. However, as also suggested by these studies, the reasons behind the validity of the EKC hypothesis are more diverse, and in the related theoretical and empirical literature, the views are also mixed. Among the researchers who provide literature surveys, critics and search into the rationale of EKC hypothesis, we mention the works of Stern et al. (1996), Borghesi (1999), Lieb (2003), Dinda (2004), Stern (2004), He (2007), Carson (2009), Bo (2011), Pasten and Figueroa (2012), Kaika and Zervas (2013a), Kaika and Zervas (2013b), Stern (2015), and Tiba and Omri (2017).

\subsection{Model specification, assumptions, econometric methodology, and identification strategy}

\subsubsection{Model specification}

The classical and probably the most used empirical strategy to model the link between environmental degradation and economic growth is through the polynomial equations of the second-, and third-degree (see e.g. Grosman and Krueger, 1991; Panayotou, 1993; and the more recent studies of Miyama and Managi, 2014; Lazăr et al., 2019; Chen et al., 2019b; among others). The use of quadratic function allows testing the traditional EKC hypothesis (i.e. the potential bellshaped pattern between pollution and growth), while the specification of a higher polynomial order, such as the cubic function, allows the representation of multiple patterns. These patterns cover the $\mathrm{N}$-shape (a potential extended EKC when the coefficient of income, squared income and cubic income is positive, negative and positive, respectively, and statistically significant), the traditional bell-shape pattern (the coefficient of income and squared income is positive and 
negative, respectively, and statistically significant), and also a monotonic increasing (decreasing) relationship when only the income coefficient is statistically significant and positive (negative). Indeed, modeling the EKC through the parametric approach implies that the functional form and also the distribution is already assumed ${ }^{5}$ (Miyama and Managi, 2014). Thus, for example, an imposed shape of the relationship through the introduction in the equation of a squared or cubic income term, when the relationship is linear, could induce weak identification, and also could bias the turning point (Bernard et al., 2014). However, to reduce the bias that may potentially arise from imposing a specific functional form, econometrically one may (i) assume the largest polynomial, i.e. cubic specification, and estimate sequentially also the quadratic and linear equation to show consistency in coefficients significance (for example, if the income terms are statistically significant in a third-order polynomial equation, intuitively in the second-order polynomial equation they should lack statistical significance; see e.g. Lazăr et al., 2019), (ii) use specific tests for the presence of a potential nonlinear relationship (see e.g. Lind and Mehlum, 2010), or (iii) employ simultaneous with the parametric techniques also the semi-, and nonparametric alternatives to assure robustness, or at least to deduce a pattern between variables descriptively (see e.g. Millimet et al., 2003; Ordás Criado et al., 2011; Bernard et al., 2014; among others). Besides, it is worth noting that not only the results obtained for the income coefficients signs, but equally, the presence or absence of a turning point helps in determining the pattern followed by the data.

A second strand of studies (see e.g. Millimet et al., 2003; Tsurumi and Managi, 2010a, 2010b; Ordás Criado et al., 2011; Chen and Chen, 2015; Sen et al., 2016; Zhang et al., 2017; Luzzati et al., 2018; among others) have challenged the classical parametric approaches, which most are based on an imposed order for the polynomial equation, by estimating the pollutionincome nexus using more flexible empirical strategies, such as semi-, and non-parametric methods. In this regard, the findings of Millimet et al. (2003) and Ordás Criado et al. (2011) show that compared to parametric counterparts, the semi-, and non-parametric alternatives are preferred when modeling the data. Although the amount of semi- and non-parametrical EKC literature has increased over the years, it remains relatively low compared to parametric one. First, one of the reasons may be related to the well-known curse of dimensionality issues in fully nonparametric

\footnotetext{
${ }^{5}$ Also, the parametric quadratic function implies symmetry since, at both sides of the threshold, the pollution increases and decrease by the same rate.
} 
models, induced when many factors are included in the equation. Bearing in mind a crucial and well-debated econometric objection about EKC, namely the omitted variable bias (see e.g. Stern, 2004), there is a need to account for at least the most influential factors of pollution along with the income (e.g. energy consumption, trade, foreign direct investments, structure of economy, globalization, economic freedom - to mention just a few of them), to obtain reliable and consistent results. Consequently, the curse of dimensionality could be a plausible impediment in applying nonparametric methods, but it can also be alleviated by working with semi-parametric methods. Second, the graphical representation results of semi- and non-parametrical models may be more complex and harder to interpret, thereby most researchers seem to prefer more straightforward results, such as point estimates. Third, the insufficiency of clear-cut statistical inference procedures in the nonparametric field could influence its soundness and applicability. Forth, usually in economics and also in energy and environmental economics sub-fields, the vast majority of studies rely on some theories or prior empirical evidence. Therefore, in most cases, the specification of the model is already predefined. Furthermore, these theories and empirical regularities - some of the well-known mentioned in the above sub-section, come along with different (parameters) assumptions and/or restrictions, which may be more convenient to address through parametric techniques. Some of these possible deficiencies of semi-, and non-parametric models are also acknowledged in the context of EKC estimation by authors such as Tsurumi and Managi (2010a) and Bernard et al. (2014), among others.

\subsubsection{Model assumptions and econometric methodology}

Although in the last two decades, some theories regarding the validity of EKC have emerged in the literature, the vast majority of the studies rely mostly only on econometric assumptions and/or restrictions (e.g. exogeneity, long-, and/or short-run homogeneity and heterogeneity, order of integration - for the independent factors; equal variance, lack of autocorrelation, normality — for residuals; persistence, order of integration — for endogenous variable; among others), in modeling the relationship between pollution and economic growth.

On the one hand, the potential econometric issues (e.g. cross-sectional dependence; timesseries properties, such as stationarity and cointegration; endogeneity bias caused by simultaneity, omitted variables, models misspecification, dynamic endogeneity or data measurement errors; among others) that can arise in estimating the pollution-growth nexus and produce biased 
estimates, if they are neglected, could be reduced by considering a (minimum) set of assumptions. However, it is generally acknowledged that both the data and sample characteristics play an essential role in dictating the choice of the most appropriate model specification and also the optimum econometric strategy. For instance, in testing EKC, the parameters homogeneity assumption in panel data models may be too restrictive, and the overall results may not describe the real general or individual pattern for each panel member (see e.g. Stern, 2010; Kaika and Zervas, 2013). Therefore, if the turning point occurs at the panel level, the behavior does not need to be preserved at the country-level, and the turning point could be well above the observed income values. As Bernard et al. (2014) point out, when working with a panel composed of different countries, disaggregation may be a valid solution to mitigate the bias of data pooling.

In the view of the previous, recent studies, such as Barra and Zotti (2017), illustrate for a sample of 120 countries spanned over 2000-2009 that once considering the nonstationarity property of the data, the evidence of an inverted $\mathrm{U}$-shape relationship between $\mathrm{CO} 2$ emissions and GDP vanishes in favor of a monotonic increasing one. Besides, to overcome the different sample composition issues, the authors eliminate alternatively from the sample the same geographical region and income distribution states. Overall, the estimates suggest that the sample composition reshapes the main findings. Furthermore, Miyama and Managi (2014), among others, suggest that excluding low-income countries from analysis due to data availability may alter the results. As such, to deal with missing data problems and its undesirable consequences on EKC estimation, they propose a series of imputation methods. Also, Stern and Common (2001) suggest that the inclusion or exclusion of developing states from the analysis may influence the occurrence of a turning point.

On the other hand, the development of novel panel ${ }^{6}$ estimators that allow for different long, and short-run slope assumptions (see e.g. the panel ARDL technique with the associated Pooled Mean-Group, Mean-Group, and Dynamic Fixed Effects estimators discussed in Pesaran et al., 1999), which are also robust to various potential econometric problems, such as the different order of integration for regressors and variables cointegration (see e.g. Pesaran and Smith, 1995; Pesaran, 2006; Eberhardt and Bond, 2009; Eberhardt and Teal, 2010), cross-sectional dependence

\footnotetext{
${ }^{6}$ We discuss here some of the recent developments of panel data techniques, as panels include both $\mathrm{N}$ and $\mathrm{T}$ dimensions, and the EKC is usually tested using panel data models. Still, it is worth mentioning that the advanced in the time-series econometric tools are more or less similar.
} 
(see e.g. Pesaran, 2006; Eberhardt and Bond, 2009; Eberhardt and Teal, 2010; Chudik and Pesaran, 2015; Chudik et al., 2016), and endogeneity (see e.g. Pesaran et al., 1999; Chudik and Pesaran, 2015; Chudik et al., 2016), facilitate the EKC estimation. Besides, the preliminary analysis techniques, such as stationarity and cointegration tests, have also been developed to deal with cross-sectional dependence, parameter heterogeneity, among other potential econometric issues. Nonetheless, taking note of the aspects mentioned above is ultimately the task of the researcher to properly formulate the set of assumptions and adapt the methods to sample particularities.

\subsubsection{Identification strategy}

The assumptions and restrictions consider by the researcher help in shaping the proper identification strategy and inference. In the light of previous EKC literature, which provides no consensus on its validity and the associated turning point, the recent landmark study of Bernard et al. (2014) waves a red flag regarding the weak identification of both EKC and the related turning point. More specifically, the authors investigate the estimation precision of the EKC turning point using Delta and Fieller method, while controlling for a wide set of potential econometric issues (i.e. endogeneity, persistence, and functional form). The overall findings show that the estimation of the EKC turning point lacks precision (i.e. the associated confidence intervals are very large) and, thus, the policy implications based on EKC may be altered. However, the results suggest that precision is higher when considering local pollutants, a long-term perspective, or nonparametric alternatives.

In the same manner, few years before the study of Bernard et al. (2014), the seminal work of Wagner (2008) and Vollebergh et al. (2009) highlights some of the most prominent weaknesses of EKC econometrics since its grounding, and raise the relevance of its identification, respectively. On the one hand, Wagner (2008) discusses two econometric issues that lately have governed the panel data EKC literature, namely the stochastic properties of nonlinear terms of integrated variables and the cross-sectional dependence. In particular, the author shows that employing standard nonstationary panel data techniques, which do not take into account the nonlinear transformations of integrated variables and cross-sectional dependence, the bell-shaped pattern between emissions and income holds. However, when using stationary de-factored data to deal with the problems mentioned above and appropriate estimation techniques, the EKC hypothesis seems to be invalidated (all the more, these findings are robust for a comprehensive set of tests, 
and when the poolability assumption is relaxed). The estimations are conducted on a reduce model between CO2 (SO2) and GDP for a panel of 100 (97) countries spanned over the period 19502000.

On the other hand, Vollebergh et al. (2009) go beyond the standard econometric issues and emphasize the relevance of a proper identification strategy as a starting point in investigating the reduced form pollution-income nexus in panel data. Considering that one can distinguish between the impact of income and time effects on pollution, the authors argue that countries alike are characterized by identical time effects. Accordingly, the corroborated estimates of the income and time effects on CO2 and SO2 emissions for 24 OECD countries over the period 1960-2000, based on the pairwise differencing technique, show that the bell-shape pattern holds only $\mathrm{SO} 2$ emissions (i.e. a locally regulated pollutant). Overall, the work of Vollebergh et al. (2009) may suggest that imposing different identifying restrictions for the exogenous variable (income) and control variable (time) yield to different model specifications, and in turn, to different findings regarding the pollution-income patterns. Besides, the authors establish a solid link between the theoretical models on EKC (see e.g. Brock and Taylor, 2005, 2010; Ordás Criado et al., 2011), and the minimal set of requirements needed for the identification of pollution-income nexus in EKC context.

In addition, Stern (2010) addresses both the issues pointed by Wagner (2008) and Vollebergh et al. (2009), namely the higher-order terms of integrated income variable, the crosssectional dependence, and the identification of income and time effects in EKC reduced models, through the between estimation technique. Using the same datasets for $\mathrm{CO} 2$ and $\mathrm{SO} 2$ emissions as Wagner (2008) and Vollebergh et al. (2009), the author shows that overall the results do not validate the traditional EKC hypothesis. In the same vein, the study of Stern et al. (2017) consider both the problems raised by Wagner (2008) and Volleberg et al. (2009) and also the omitted variable bias of between estimator employed in Stern (2010). As such, to mitigate their related undesirable effects on EKC results, the authors suggest working to long-run growth rates of pollution and income variables, while adding additional factors to account for the variation around the trend. The findings indicate that the EKC is not at work both for the full sample of $\mathrm{CO} 2$ and SO2 emissions. Moreover, Sen et al. (2016) use a slightly modified identification strategy for income and time effects, based on the pairwise differencing approach as Vollebergh et al. (2009), and further control for the potential issues caused by nonstationarity, employing nonlinear 
nonstationary parametric and nonparametric techniques. The overall findings indicate that the time effects do not have the power to detract the positive income effects, pointing out that the regional CO2 EKC hypothesis is not at work for the period 1950-2010.

Here we discussed some of the latest most influential studies that couple the EKC with the relevance of identification procedures. The general idea of these studies lies in the fact that a large part of the empirical EKC literature lacks in providing a (reasonable) identification strategy, which reflects in misleading findings concerning its validity and the computation of associated turning point. Consequently, the identification of the pollution-growth nexus should no be "taking as is given", but rather assembled through convincing assumptions and investigated using appropriate econometric tools.

\section{CO2 emissions stylized facts: a short descriptive empirical exercise}

Clear evidence of deterioration in the quality of the environment is the sharp increase in greenhouse gas (GHG) emissions following human activities, in the post-industrial period, compared to the levels recorded prior to it. Also, $\mathrm{CO} 2$ is considered to be the greatest environmental threat, given the rapidity that its concentrations have increased over the years. During the pre-industrial period, the atmospheric $\mathrm{CO} 2$ concentration resulting from the combustion of fossil fuels is about 280 parts per million (ppm) ${ }^{7}$, while in 2016, it reaches about $403 \mathrm{ppm}$, on average. Put differently, due to fossil fuel combustion and cement production, in 2016, the atmospheric CO2 is $145 \%$ above pre-industrial levels (see World Meteorological Organization, 2017) ${ }^{8}$.

Moreover, the CO2 emissions account for $72 \%$ of global GHG emissions in 2016, while $50 \%$ of this $\mathrm{CO} 2$ emissions come from electricity and heat production together with the industry sector. According to Olivier et al. (2017), the top six CO2 emitters in 2016 are China, the United States (US), India, the Russian Federation, Japan, and the European Union(28) (EU28), being responsible for approximatively $68 \%$ and $63 \%$ of total global CO2 and total GHG emissions, respectively. However, in 2016, the CO2 emissions decline in the Russian Federation (-2.1\%), US $(-2.0 \%)$, Japan $(-1.2 \%)$ and China $(-0.3 \%)$, while an increase is registered in India $(4.7 \%)$ and the EU(28) (0.2\%) (Olivier et al., 2017). Besides, the CO2 emissions are just an example of an air

\footnotetext{
${ }^{7}=$ number of molecules of the gas per million (106) molecules of dry air.

${ }^{8}$ https://ane4bf-datap1.s3-eu-west-1.amazonaws.com/wmocms/s3fspublic/ckeditor/files/GHG_Bulletin_13_EN_final_1_1.pdf?LGJNmHpwKkEG2Qw4mEQjdm6bWxgWAJHa
} 
pollutant that contributes to the degradation of the environment, but the spectrum is much broader (e.g. air, water, land, noise, and light pollutants). Indeed, a vast majority of empirical studies have used $\mathrm{CO} 2$ emissions as a proxy for environmental degradation (see e.g. Table 2 and Table 3 in the next section). Perhaps, its importance to climate change and data availability have determined the researchers to focus more on its related impacts, in comparison to other types of pollutants.

Consequently, considering four out of six top CO2 emitters mentioned above [i.e. China, India, the Russian Federation, and the EU(28)], and also the global level (i.e. the World), we illustrate the relationship between $\mathrm{CO} 2$ emissions and GDP per capita descriptively ${ }^{9}$, using both descriptive and nonparametric statistical techniques. Regarding the nonparametric techniques, we employ the local linear, local polynomial, and lowess nonparametric regressions models to better disentangle the pattern between $\mathrm{CO} 2$ pollution and economic growth. In doing so, we consider the standard specification of a general nonparametric model as follows:

$$
y=\phi(x)+\varepsilon
$$

We proxy environmental degradation by $\mathrm{CO} 2$ emissions per capita and economic growth by GDP per capita. The data are collected from the World Bank (2018) and the Janssens-Maenhout et al. (2017), for the period $1970-2016^{10}$. Next, equation (1) becomes:

$$
C O 2=\phi(G D P)+\varepsilon
$$

The $\mathrm{CO} 2$ is the endogenous variable, GDP is the predictor variable and $\varepsilon \sim N I D\left(0, \sigma^{2}\right)$ the error term. $\phi($.$) denotes the unknown smooth continuous function, whose functional form is not$ specified, i.e. is estimated based on data ${ }^{11}$.

Column [A] from Figure 1 displays the evolution of CO2 emissions and GDP for each country. In contrast, column [B] and column [C] shows the scatter plot between indicators, and the curve fitting of nonparametric regressions ${ }^{12}$, respectively. First, we can observe that China, India, and the World exhibit a relatively smooth monotonically increasing relationship. At the same time,

\footnotetext{
${ }^{9}$ We exclude Japan and the US from our analysis, considering that they belong to the group of developed countries. However, we keep the EU(28) and include the World as they also comprise the developing and transition countries.

${ }^{10}$ Due to data availability for the EU(28), the Russian Federation, and at the global level, the period covered is 19902016. Also, in the empirical analysis, we use the natural logarithm of the data.

11 For more information related to nonparametric regression models, see Cleveland (1979), Cleveland (1981), Robinson (1983), Cleveland and Devlin (1988), Cleveland and Loader (1996), Henderson and Parameter (2015), among others.

${ }^{12}$ We present the nonparametric regression models solely in a descriptive way, to better visualize and disentangle the pollution-growth nexus patterns. As such, we do not concern ourselves with variable nonstationary, cointegration, and other technical aspects related to time-series econometrics, these being beyond the aim of the present study. However, we note that some of those aspects are discussed during the paper theoretically.
} 
in the EU(28), and the Russian Federation, the nonlinearities are more pronounced. Second, overall, the pollution decreases with economic development in the EU(28), and we note the opposite in the remaining cases. Third, judging at the descriptive level, the EKC hypothesis seems to hold only for the Russian Federation. Altogether, the straightforward descriptive analysis from Figure 1 emphasizes some important disparities related to the relationship between $\mathrm{CO} 2$ emissions and growth among countries considered. In the next section, we aim at presenting more in-depth empirical findings related to pollution-growth patterns of some recent studies that have tested the EKC hypothesis.

[A]
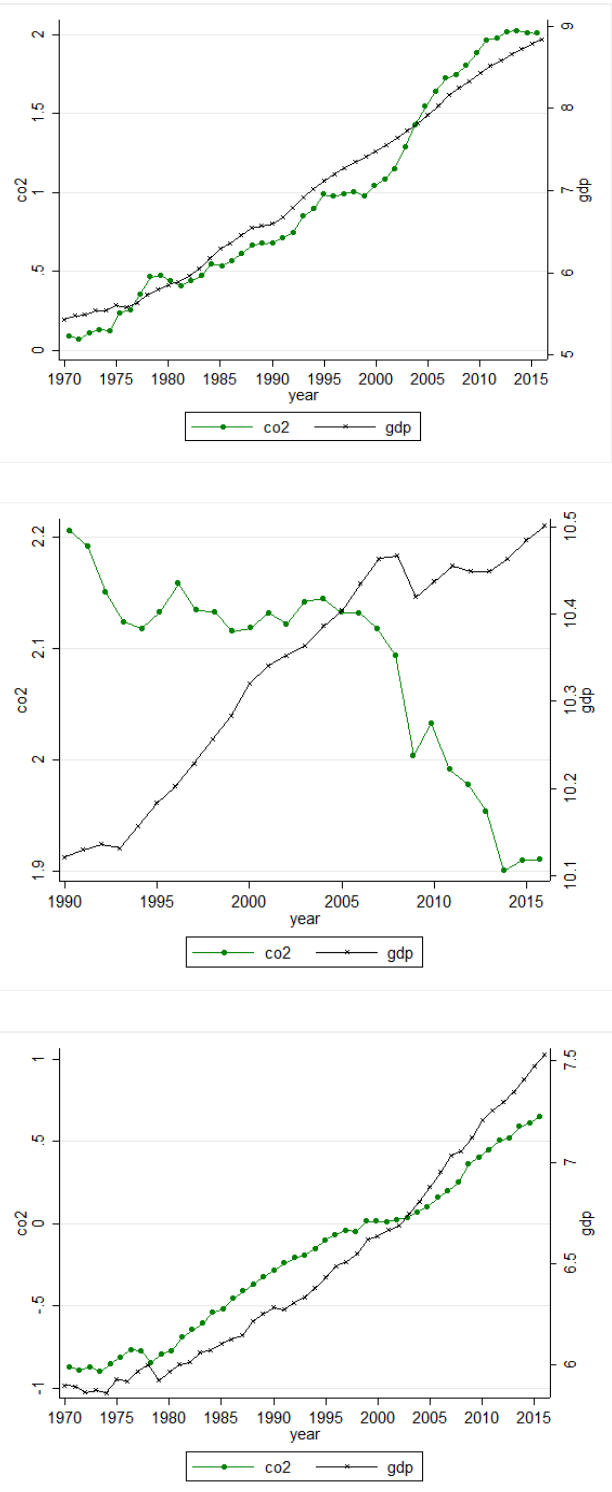

Figure 1. CO2-GDP nexus graphs

[B]

China

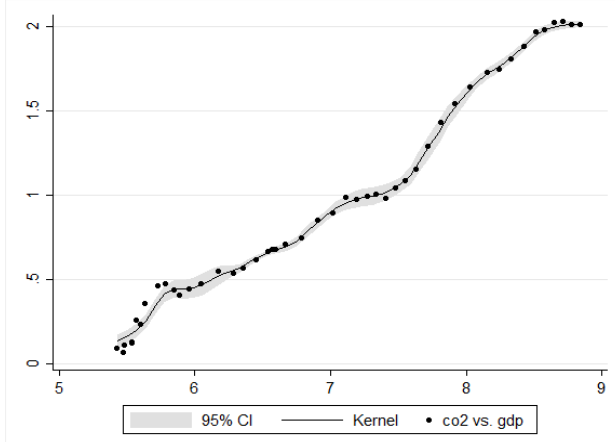

European Union(28)
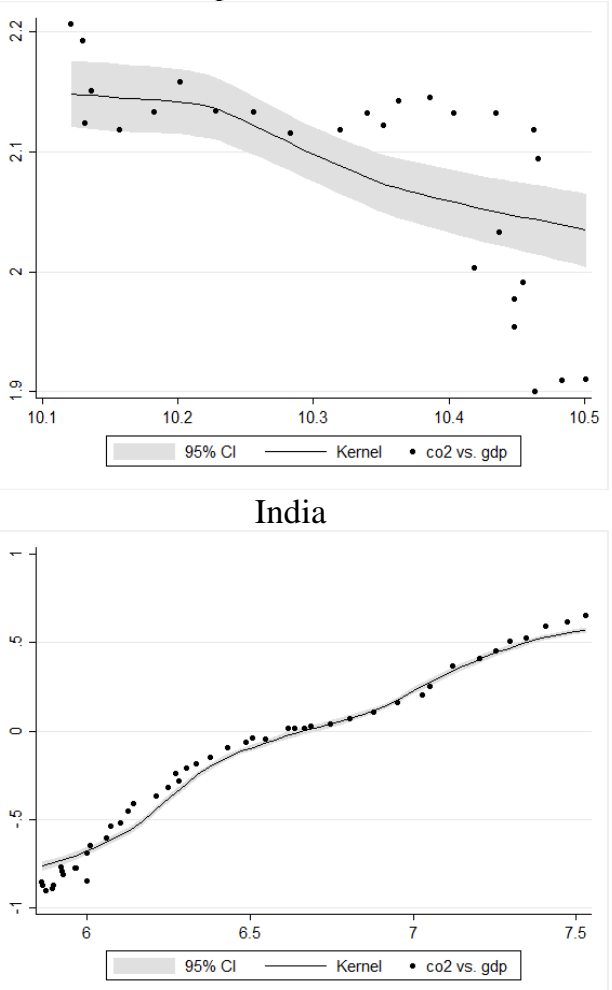

Russian Federation
[C]
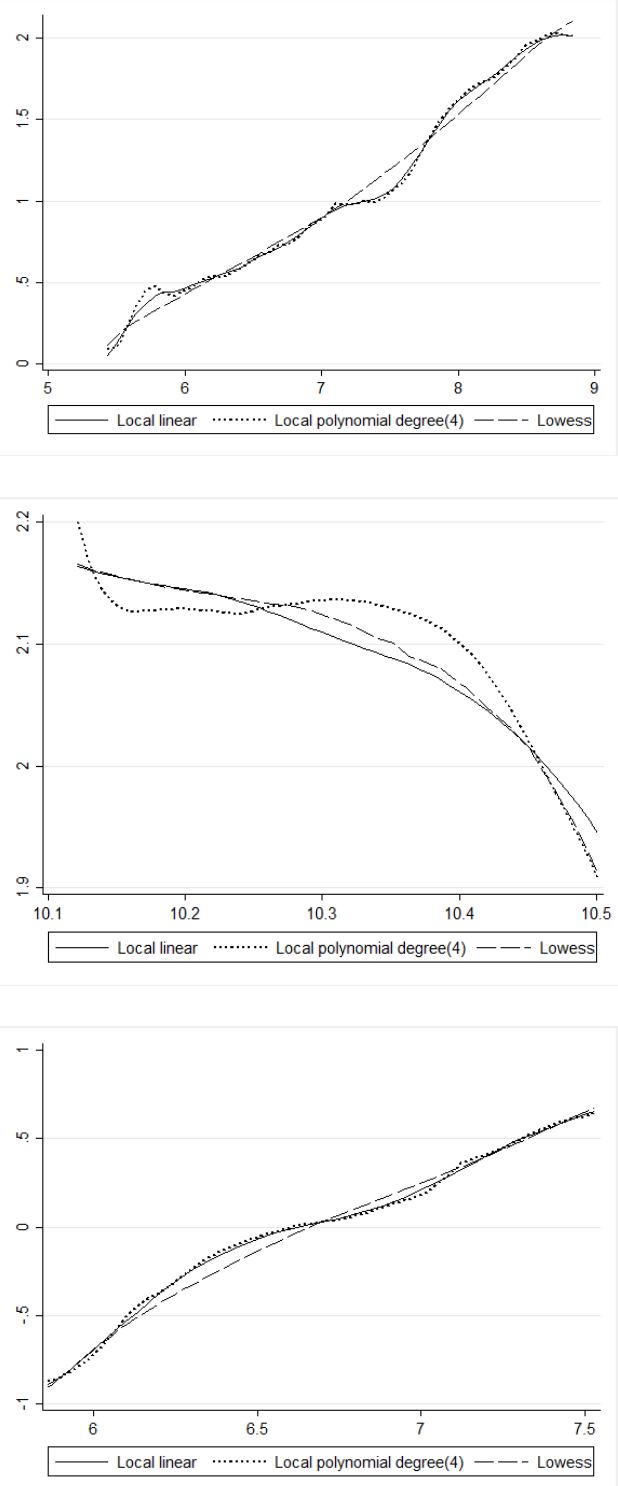

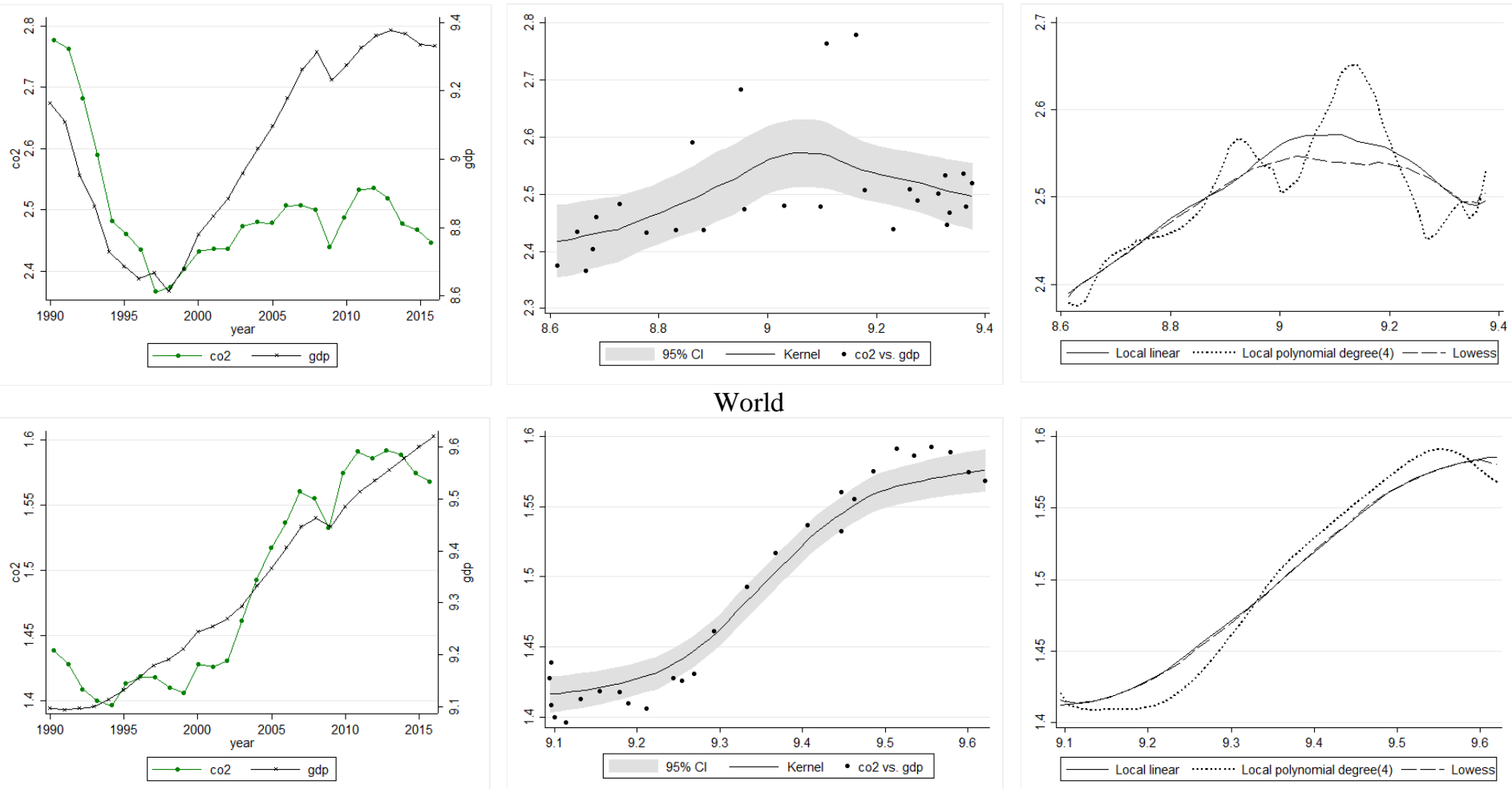

Notes: Column [A] shows the evolution of $\mathrm{CO} 2$ emissions and GDP per capita during the period analyzed. In column [B], along with the scatterplot, we fitted a local constant kernel regression with 95\% confidence bands. In column [C], we performed a local linear, local polynomial of degree(4) and lowess regression. For the kernel, local linear, and local polynomial, we specify the default Epanechnikov function and (0.1) bandwidth. The default bandwidth option is used for lowess regression.

\section{Empirical literature review on EKC hypothesis}

Our survey attempts to bring together some of the papers that have stressed the relationship between pollution and growth through the EKC hypothesis for developing and transition states, and are published in the literature during the period from 2010 to $2019^{13}$. In this respect, first, we divide our empirical literature review into three parts, namely panel data analysis, time-series analysis, and the last part, which addresses some of the new perspectives on modeling environmental degradation and economic growth nexus. The first two parts are related to the timedomain approach ${ }^{14}$, while the last one lies both in time- and time-frequency-domain. Moreover, each of these parts corresponds to one standalone sub-section as below. Second, related to each paper, we provide information about the authors and the year of publication, sample, time-span, empirical methodology, endogenous variable, pollution-growth pattern, and the estimated income

\footnotetext{
${ }^{13}$ We note that the review of the literature is not exhaustive, as we include studies published between 2010 and 2019 in popular journals on the subject, which meet the needs of the present work.

${ }^{14}$ The studies that embody both types of analysis are included in the section in which we consider that the primary analysis harmonize.
} 
turning point value.

\subsection{Panel data analysis}

Table 2 displays the studies that use panel data models to explore the EKC hypothesis. For a more homogeneous view, we split the items based on the specific technique approached, namely cointegration techniques and other panel data methods.

The first strand of studies uses larger groups of countries, which are further divided according to income level, and test the EKC hypothesis for the sub-samples of developing and/or transition countries (see Albulescu et al., 2019; Chen et al., 2019; Kim et al., 2019; Ridzuan, 2019; Alvarado et al., 2018; Luzzati et al., 2018; Omri, 2018; and Ulucak and Bilgili, 2018). The majority of these works use $\mathrm{CO} 2$ emissions as the leading indicator of environmental pollution, except Ulucak and Bilgili (2018), who proxy environmental degradation with the ecological footprint, and Chen et al. (2019) and Rizduan (2019) who use local pollutants. Moreover, two studies out of eight, namely Omri (2018) and Ulucak and Bilgili (2018), employ cointegration techniques, and both provide evidence in favor of the traditional EKC hypothesis. Likewise, the remaining works employ other panel data models, such as FE, RE, 2SLS, quantile regression models or semi-, and non-parametric models. Overall, the findings indicate a bell-shaped pattern between pollution and growth (with the notable exception of Luzzati et al., 2018, who find a monotonically increasing pattern for $\mathrm{CO} 2$ emissions and a $\mathrm{U}$-shaped pattern for total primary energy supply). Regarding the turning point, Chen et al. (2019), for the inverted U-shaped curve, estimate that its value in per capita terms equals 9112.90 US\$ (PM2.5), 8102.51 US\$ (PM10), and 9901.53 US\$ (SO2), while Luzzati et al. (2018), for the U-shaped curve, find that its value is 498 US\$ (total primary energy supply).

The second strand of studies investigates the EKC validity considering almost exclusively developing and transition economies samples. In this regard, Leblois et al. (2017) examine the deforestation rate EKC hypothesis for a group of 128 developing countries over the period 20022010. Based on the FE estimator, the results suggest the lack of a significant statistical link between environmental degradation and economic growth. In the same vein, Culas (2012) explores the relationship between the rate of deforestation and growth for 43 tropical developing nations, categorized by geographical region, namely, Latin America, Africa, and Asia. The findings reveal a bell-shaped pattern for Latin America and Africa, with a turning point computed at 6072 and 
1483 US\$ per capita, respectively. For Asia, the relationship is found to be U-shaped, and the level of GDP for which the rate of deforestation switches its trend is about 2320 US\$ per capita. Also, Joshi and Beck (2018) point out that the relationship between CO2 emissions and growth for 87 non-OECD countries is monotonically increasing. Hove and Tursoy (2019) and Özokcu and Özdemir (2017) also test the EKC hypothesis for 24 and 52 emerging countries, respectively. The former authors show that the pattern is inverted U-shaped (U-shaped) for nitrous oxide emissions (CO2 emissions and fossil fuel consumption). In contrast, the latter authors unveil an N-shape pattern for $\mathrm{CO} 2$ emissions.

Furthermore, to examine the pollution-growth pattern several researcher use specific group of countries, namely MENA or Middle East states (Arouri et al., 2012; Ozcan, 2013; Charfeddine and Mrabet, 2017), BRIC states (Pao and Tsai, 2010, 2011), African states (Osabuohien et al., 2014; Awad et al., 2019), ASEAN or Asian states (Hanif et al., 2019; Nasir et al., 2019), CEE states (Lazăr et al., 2019), SAARC states (Waqih et al., 2019), or newly industrialized states (Destek and Sarkodie, 2019). As such, Arouri et al. (2012) validate the CO2 EKC hypothesis for 12 MENA states covering the period 1981-2005. The turning point of CO2 emissions is found for a GDP level of 37,263 US\$ per capita. Charfeddine and Mrabet (2017) test the EKC hypothesis for ecological footprint using a sample of 15 MENA countries observed over the period 19952007. The empirical findings suggest a bell-shaped pattern for the whole sample and oil-exporting countries and a U-shaped pattern for non-oil-exporting countries. Likewise, the results provided by Ozcan (2013), based on the FMOLS estimator, unveil a U-shaped pattern between CO2 emissions and growth, with an income threshold equals to 8.23 in logs. The study is conducted for 12 Middle East nations, span over the period from 1990 to 2008. Also, using cointegration techniques, Pao and Tsai $(2010,2011)$ confirm the presence of the bell-shaped pattern between $\mathrm{CO} 2$ emissions and growth in BRIC countries. The computed income turning points for the convex curve are 5.638 and 5.393 in logs, respectively. Moreover, Awad et al. (2019) for 46 African states and Osabuohien et al. (2014) for 50 African states find evidence in favor of the EKC hypothesis, both for $\mathrm{CO} 2$ emissions and air pollution measured as mean annual exposure, and CO2 and PM10 emissions, respectively. In the same vein, for 15 developing Asian states using the ARDL approach, Hanif et al. (2019), validate the CO2 EKC hypothesis, while Nasir et al. (2019) for 5 ASEAN economies using FMOLS and DOLS estimators unveil a monotonically increasing pattern. Besides, the findings of Destek and Sarkodie (2019) for 11 newly industrialized countries, 
and Waqih et al., (2019) for 4 SAARC countries, using panel cointegration techniques, reveal a bell-shaped pattern for ecological footprint and CO2 emissions, respectively. Also, Lazăr et al. (2019) unveil a monotonically increasing pattern between economic growth and a series of pollution indicators, such as CO2 emissions, SO2 emissions, biocapacity, and ecological footprint. The authors employ a series of heterogeneous panel estimators, namely MG-FMOLS, MG, and AMG, for CEE states over the period 1996-2015. On this last point, it is worth noting that all these papers use panel cointegration techniques to investigate the pollution-growth nexus pattern.

The third strand of works uses panel data models to investigate the pattern between pollution and growth for Chinese provinces. In this regard, a group of studies shows that EKC is at work for Chinese provinces (Du et al., 2012; Chen and Chen, 2015; Hao et al., 2016; Li et al., 2016; Wang et al., 2016; Zhang et al., 2017; Chen et al., 2018; Hao et al., 2018b; Wenbo and Yan, 2018; Liu et al., 2019), while other studies reveal either an inverted N-shaped pattern (Liu et al., 2015; Kang et al., 2016; Li et al., 2019; Zhao et al., 2019) or a monotonically increasing pattern (Yang et al., 2015). More specifically, evidence in favor of EKC hypothesis is found for CO2 emissions (Du et al., 2012; Chen and Chen, 2015; Li et al., 2016; Chen et al., 2018; Wenbo and Yan, 2018; Liu et al., 2019), CO2 emission intensity (Wenbo and Yan, 2018), SO2 emissions (Wang et al., 2016), coal consumption (Hao et al., 2016), wastewater and solid waste emissions (Li et al., 2016), COD and NH3-N emissions (Zhang et al., 2017), and soot and dust emissions (Chen et al., 2018). Moreover, the inverted N-shaped pattern occurs for CO2 emissions (Liu et al., 2015; Kang et al., 2016), SO2 emissions and solid waste (Zhao et al., 2019), and carbon intensity of human wellbeing (Li et al., 2019). Besides, Yang et al. (2015) find a monotonically increasing relationship for CO2 emissions and industrial gas, while Hao et al. (2018b) a U-shaped pattern for the environmental quality index, which translates in a bell-shaped one, as the dependent variable is an inverse indicator of environmental degradation. With respect to the income turning points, the recent studies of Li et al. (2019) and Zhao et al. (2019) show that their estimated values based on the inverted $\mathrm{N}$-shaped curve are 850 and 110,000 yuan per capita for carbon intensity of human wellbeing, and 4057 and 24,484 yuan per capita (4298 and 33,355 yuan per capita) for SO2 emissions (solid waste), respectively. Moreover, for CO2 emissions, Chen and Chen (2015) and Liu et al. (2019) find an income peak of the bell-shaped curve equals to 49,813.79 and 55,297.3 yuan per capita, respectively. Hao et al. (2016) show that the value of the income threshold of the coal consumption bell-shaped curve ranges between 18,456 to 23,585 yuan per capita $(39,692$ to 
48,521 yuan per capita) for classical panel models (spatial panel models). Additionally, studies such as Du et al. (2012), Kang et al. (2016), Li et al. (2016), Hao et al. (2018b), and Li et al. (2019) find turning points that lie outside the income range values. However, the EKC patterns and the estimated turning points depend on the sample size (i.e. the number of provinces included), the period analyzed, and the proxy used for environmental degradation.

Other studies examine the EKC hypothesis either for the economic sectors of Iranian provinces (Dehghan Shabani and Shahnazi, 2019), metropolitan regions of Republic of Korea (Park and Lee, 2011), Indian cities (Sinha and Bhattacharya, 2017), or Chinese cities (Stern and Zha, 2016; Hao et al., 2018a). On the one hand, the results of Dehghan Shabani and Shahnazi (2019) based on the DOLS estimator illustrate that the EKC is at work for the period 2002-2013 for all economic sectors (i.e. agricultural, industrial, transportation, and services sector). However, the estimated turning points, namely 0.134 in $\operatorname{logs}$ (agricultural sector), 0.918 in logs (industrial sector), 0.880 in logs (transportation sector), and 0.555 in logs (services sector), are above the average GDP value for each sector. On the other hand, Sinha and Bhattacharya (2017) use a sample of 139 Indian cities and test the SO2 EKC hypothesis for the period 2001-2013. Overall, the authors find a bell-shaped pattern for industrial and industrial high-income areas, while for industrial low-income areas, the relationship seems to be $\mathrm{N}$-shaped. Also, for residential areas, the $\mathrm{SO} 2$ growth nexus pattern does not exhibit nonlinearities. The SO2 emissions peak varies from 18.87 to 1110.10 Rs. Lacs, for the electricity consumption model, and from 20.51 to 1564.36 Rs. Lacs, for the petroleum consumption model, according to income level sub-samples. Both the lowest values, i.e. 18.87 and 20.51, are situated outside the income range values. In the same vein, Stern and Zha (2016) investigate the EKC hypothesis for 50 Chinese cities over the period 20132014 using both the growth rates and traditional EKC models. Overall, according to both approaches, the pattern between pollution and growth seems to be U-shaped. Also, the computed turning point based on the traditional model and FE estimator is 453,454 RMB per capita for PM2.5 (yet not statistically significant) and 87,493 RMB per capita for PM10. Also, Hao et al. (2018a) test the pollution-growth nexus pattern for 283 Chinese cities span over 2003-2010. The authors use three environmental degradation indicators, namely SO2 emissions, industrial soot emissions, and industrial wastewater discharge, and apply the GMM technique. They show that the inverted U-shaped curve holds for soot emissions, while for SO2 emissions, the pattern is Ushaped. Furthermore, using a dataset of 16 metropolitan regions from the Republic of Korea, 
covering the period 1990-2005, Park and Lee (2011) show that relationship form between SO2 emissions and growth is N-shaped (with the peak equals to 5700 US\$ and the trough equals to 28,000 US\$ per capita). Conversely, a U-shaped curve is at work for CO2 emissions (with the peak that ranges from 26,400 US\$ to 30,000 US\$ per capita) and NO2 emissions (with the peak equals to 27,600 US\$ per capita).

Table 2. Panel data literature survey

\begin{tabular}{|c|c|c|c|c|c|c|}
\hline Author & Sample & Period & Methodology & $\begin{array}{l}\text { Endogenous } \\
\text { variable }\end{array}$ & $\begin{array}{l}\text { Pollution-growth } \\
\text { pattern }\end{array}$ & Turning point \\
\hline \multicolumn{7}{|c|}{ Cointegration analysis } \\
\hline $\begin{array}{l}\text { Awad et al. } \\
(2019)\end{array}$ & $\begin{array}{l}46 \text { African } \\
\text { countries }\end{array}$ & 1990-2017 & FMOLS, DOLS & $\begin{array}{l}\text { CO2 emissions, air } \\
\text { pollution measured } \\
\text { as mean annual } \\
\text { exposure }\end{array}$ & Bell-shape & - \\
\hline $\begin{array}{l}\text { Dehghan } \\
\text { Shabani and } \\
\text { Shahnazi } \\
\text { (2019) }\end{array}$ & $\begin{array}{l}28 \text { provinces of } \\
\text { Iran }\end{array}$ & $2002-2013$ & DOLS & $\mathrm{CO} 2$ emissions & Bell-shape & $\begin{array}{l}0.134 * \text { in } \operatorname{logs} \\
\text { (agricultural sector), } \\
0.918 * \text { in logs } \\
\text { (industrial sector), } \\
0.880 * \text { in logs } \\
\text { (transportation sector), } \\
0.555^{*} \text { in logs (services } \\
\text { sector) }\end{array}$ \\
\hline $\begin{array}{l}\text { Destek and } \\
\text { Sarkodie } \\
(2019)\end{array}$ & $\begin{array}{l}11 \text { newly } \\
\text { industrialized } \\
\text { countries }\end{array}$ & $1977-2013$ & AMG & Ecological footprint & Bell-shape & - \\
\hline $\begin{array}{l}\text { Hanif et al. } \\
(2019)\end{array}$ & $\begin{array}{l}15 \text { Asian } \\
\text { developing } \\
\text { countries }\end{array}$ & 1990-2013 & ARDL & $\mathrm{CO} 2$ emissions & Bell-shape & - \\
\hline $\begin{array}{l}\text { Lazăr et al. } \\
(2019)\end{array}$ & $11 \mathrm{CEE}$ countries & 1996-2015 & $\begin{array}{l}\text { MG-FMOLS, } \\
\text { MG, AMG }\end{array}$ & $\begin{array}{l}\mathrm{CO} 2 \text { emissions, } \mathrm{SO} 2 \\
\text { emissions, } \\
\text { biocapacity, } \\
\text { ecological footprint }\end{array}$ & $\begin{array}{l}\text { Monotonically } \\
\text { increasing }\end{array}$ & - \\
\hline $\begin{array}{l}\text { Nasir et al. } \\
(2019)\end{array}$ & $\begin{array}{l}5 \text { ASEAN } \\
\text { countries }\end{array}$ & $1982-2014$ & FMOLS, DOLS & $\mathrm{CO} 2$ emissions & $\begin{array}{l}\text { Monotonically } \\
\text { increasing }\end{array}$ & - \\
\hline $\begin{array}{l}\text { Waqih et al. } \\
(2019)\end{array}$ & $\begin{array}{l}4 \text { SAARC } \\
\text { countries }\end{array}$ & 1986-2014 & ARDL, FMOLS & $\mathrm{CO} 2$ emissions & Bell-shape & - \\
\hline Omri (2018) & $\begin{array}{l}69 \text { countries } \\
\text { (high-income } \\
\text { countries, upper- } \\
\text { middle-income } \\
\text { countries, lower- } \\
\text { middle-income } \\
\text { countries, low- } \\
\text { income countries) }\end{array}$ & $2001-2011$ & FMOLS & CO2 emissions & $\begin{array}{l}\text { Bell-shape (lower- } \\
\text { middle-income } \\
\text { countries, low- } \\
\text { income countries) }\end{array}$ & - \\
\hline $\begin{array}{l}\text { Ulucak and } \\
\text { Bilgili (2018) }\end{array}$ & $\begin{array}{l}45 \text { countries (low- } \\
\text { income countries, } \\
\text { middle-income } \\
\text { countries, high- } \\
\text { income countries) }\end{array}$ & 1961-2013 & $\begin{array}{l}\text { CUP-FM, CUP- } \\
\text { BC }\end{array}$ & Ecological footprint & $\begin{array}{l}\text { Bell-shape (low- } \\
\text { income countries) }\end{array}$ & - \\
\hline $\begin{array}{l}\text { Charfeddine } \\
\text { and Mrabet } \\
(2017)\end{array}$ & $\begin{array}{l}15 \text { MENA } \\
\text { countries }\end{array}$ & 1975-2007 & FMOLS, DOLS & Ecological footprint & $\begin{array}{l}\text { Bell-shape (panel, } \\
\text { oil-exporting } \\
\text { countries), U-shape }\end{array}$ & - \\
\hline
\end{tabular}




\begin{tabular}{|c|c|c|c|c|c|c|}
\hline & & & & & $\begin{array}{l}\text { (non-oil-exporting } \\
\text { countries) }\end{array}$ & \\
\hline $\begin{array}{l}\text { Osabuohien et } \\
\text { al. (2014) }\end{array}$ & $\begin{array}{l}50 \text { African } \\
\text { countries }\end{array}$ & $1995-2010$ & DOLS & $\begin{array}{l}\text { CO2 emissions, } \\
\text { PM10 emissions }\end{array}$ & Bell-shape & - \\
\hline Ozcan (2013) & $\begin{array}{l}12 \text { Middle East } \\
\text { countries }\end{array}$ & 1990-2008 & FMOLS & $\mathrm{CO} 2$ emissions & Ushape & 8.23 in logs \\
\hline $\begin{array}{l}\text { Arouri et al. } \\
(2012)\end{array}$ & $\begin{array}{l}12 \text { MENA } \\
\text { countries }\end{array}$ & $1981-2005$ & CCE-MG & CO2 emissions & Bell-shape & $\begin{array}{l}37,263 \text { US\$ per capita } \\
\{\text { constant } 2005\}\end{array}$ \\
\hline $\begin{array}{l}\text { Pao and Tsai } \\
(2011)\end{array}$ & BRIC countries & $\begin{array}{l}\text { 1980-2007, } \\
1992-2007 \\
\text { (Russia) }\end{array}$ & $\begin{array}{l}\text { Cointegration } \\
\text { techniques }\end{array}$ & $\mathrm{CO} 2$ emissions & Bell-shape & 5.638 in $\log s$ \\
\hline $\begin{array}{l}\text { Pao and Tsai } \\
(2010)\end{array}$ & BRIC countries & $\begin{array}{l}\text { 1971-2005, } \\
1990-2005 \\
\text { (Russia) }\end{array}$ & $\begin{array}{l}\text { Cointegration } \\
\text { techniques }\end{array}$ & $\mathrm{CO} 2$ emissions & Bell-shape & 5.393 in logs \\
\hline \multicolumn{7}{|c|}{ Other panel data models } \\
\hline $\begin{array}{l}\text { Albulescu et al. } \\
\text { (2019) }\end{array}$ & $\begin{array}{l}14 \text { Latin America } \\
\text { countries (high- } \\
\text { income countries, } \\
\text { low-income } \\
\text { countries) }\end{array}$ & $1980-2010$ & $\begin{array}{l}\mathrm{FE}, \mathrm{RE}, \mathrm{FE} \text { panel } \\
\text { quantiles } \\
\text { regression }\end{array}$ & $\mathrm{CO} 2$ emissions & $\begin{array}{l}\text { Bell-shape for the } \\
\text { first quantiles (low- } \\
\text { income countries) }\end{array}$ & - \\
\hline $\begin{array}{l}\text { Chen et al. } \\
(2019)\end{array}$ & $\begin{array}{l}62 \text { countries (35 } \\
\text { more developed } \\
\text { countries, } 27 \text { less } \\
\text { developed } \\
\text { countries) }\end{array}$ & $1970-2012$ & FE, 2SLS & $\begin{array}{l}\text { PM2.5 emissions, } \\
\text { PM10 emissions, } \\
\text { SO2 emissions }\end{array}$ & $\begin{array}{l}\text { Bell-shape (27 less } \\
\text { developed countries) }\end{array}$ & $\begin{array}{l}\text { 9112.90 US\$ per capita } \\
\text { (PM2.5), 8102.51 US\$ } \\
\text { per capita (PM10), } \\
9901.53 \text { US\$ per capita } \\
\text { (SO2) } \\
\{\text { constant } 2010\}\end{array}$ \\
\hline $\begin{array}{l}\text { Hove and } \\
\text { Tursoy (2019) }\end{array}$ & $\begin{array}{l}24 \text { emerging } \\
\text { economies }\end{array}$ & $2000-2017$ & GMM & $\begin{array}{l}\mathrm{CO} 2 \text { emissions, } \\
\text { fossil fuel energy } \\
\text { consumption, } \\
\text { nitrous oxide } \\
\text { emissions }\end{array}$ & $\begin{array}{l}\text { Bell-shape (nitrous } \\
\text { oxide emissions), U- } \\
\text { shape (CO2 } \\
\text { emissions, fossil fuel } \\
\text { consumption) }\end{array}$ & - \\
\hline $\begin{array}{l}\text { Kim et al. } \\
(2019)\end{array}$ & $\begin{array}{l}131 \text { countries } \\
\text { (developing } \\
\text { countries, } \\
\text { advanced } \\
\text { countries) }\end{array}$ & $1960-2013$ & $\begin{array}{l}\text { Panel data IV } \\
\text { quantile } \\
\text { regression }\end{array}$ & $\mathrm{CO} 2$ emissions & $\begin{array}{l}\text { Bell-shape } \\
\text { (developing } \\
\text { countries) }\end{array}$ & - \\
\hline Li et al. (2019) & $\begin{array}{l}30 \text { provinces of } \\
\text { China }\end{array}$ & $1995-2016$ & $\begin{array}{l}\text { Spatial panel } \\
\text { models }\end{array}$ & $\begin{array}{l}\text { Carbon intensity of } \\
\text { human wellbeing }\end{array}$ & Inverted-N shape & $\begin{array}{l}850 \text { yuan per capita and } \\
110,000 * \text { yuan per } \\
\text { capita } \\
\{\text { constant } 2000\}\end{array}$ \\
\hline $\begin{array}{l}\text { Liu et al. } \\
\text { (2019) }\end{array}$ & $\begin{array}{l}29 \text { provinces of } \\
\text { China }\end{array}$ & 1996-2015 & $\begin{array}{l}\text { FE panel data } \\
\text { partially linear } \\
\text { additive model }\end{array}$ & $\mathrm{CO} 2$ emissions & Bell-shape & $\begin{array}{l}55,297.3 \text { yuan per } \\
\text { capita } \\
\text { \{deflated to the } 1996 \\
\text { consumer price index }\end{array}$ \\
\hline Ridzuan (2019) & $\begin{array}{l}\text { 170/174 countries } \\
\text { (high-income } \\
\text { countries, low- } \\
\text { income countries) }\end{array}$ & $1991-2010$ & $\begin{array}{l}\text { Driscoll and } \\
\text { Kraay } \\
\text { nonparametric } \\
\text { variance- } \\
\text { covariance } \\
\text { estimator }\end{array}$ & SO2 emissionas & $\begin{array}{l}\text { Bell-shape (low- } \\
\text { income countries) }\end{array}$ & - \\
\hline $\begin{array}{l}\text { Zhao et al. } \\
\text { (2019) }\end{array}$ & $\begin{array}{l}30 \text { provinces of } \\
\text { China }\end{array}$ & 1999-2017 & $\begin{array}{l}\text { Spatial regression } \\
\text { models }\end{array}$ & $\begin{array}{l}\text { SO2 emissions, } \\
\text { solid waste, } \\
\text { wastewater }\end{array}$ & $\begin{array}{l}\text { Inverted-N shape } \\
\text { ( } \mathrm{SO} 2 \text { emissions, } \\
\text { solid waste) }\end{array}$ & $\begin{array}{l}4057 \text { and } 24,484 \text { yuan } \\
\text { per capita (SO2), } 4298\end{array}$ \\
\hline
\end{tabular}




\begin{tabular}{|c|c|c|c|c|c|c|}
\hline & & & & discharge & & $\begin{array}{l}\text { and } 33,355 \text { yuan per } \\
\text { capita (solid waste) } \\
\text { \{constant } 2000\}\end{array}$ \\
\hline $\begin{array}{l}\text { Alvarado et al. } \\
\text { (2018) }\end{array}$ & $\begin{array}{l}151 \text { countries } \\
\text { (high-income } \\
\text { countries, middle- } \\
\text { high-income } \\
\text { countries, middle- } \\
\text { low-income } \\
\text { countries, low- } \\
\text { income countries) }\end{array}$ & $1980-2016$ & FE, RE & $\mathrm{CO} 2$ emissions & $\begin{array}{l}\text { Bell-shape (middle- } \\
\text { low-income } \\
\text { countries) }\end{array}$ & - \\
\hline $\begin{array}{l}\text { Chen et al. } \\
\text { (2018) }\end{array}$ & $\begin{array}{l}30 \text { provinces of } \\
\text { China }\end{array}$ & $1998-2012$ & GMM & $\begin{array}{l}\mathrm{CO} 2 \text { emissions, soot } \\
\text { and dust emissions, } \\
\text { wastewater } \\
\text { discharge }\end{array}$ & $\begin{array}{l}\text { Bell-shape (CO2 } \\
\text { emissions, soot and } \\
\text { dust emissions) }\end{array}$ & - \\
\hline $\begin{array}{l}\text { Hao et al . } \\
\text { (2018a) }\end{array}$ & 283 Chinese cities & $2003-2010$ & GMM & $\begin{array}{l}\mathrm{SO} 2 \text { emissions, } \\
\text { industrial soot } \\
\text { emissions, industrial } \\
\text { wastewater } \\
\text { discharged }\end{array}$ & $\begin{array}{l}\text { Bell-shape (soot } \\
\text { emissions), U-shape } \\
\text { (SO2 emissions) }\end{array}$ & - \\
\hline $\begin{array}{l}\text { Hao et al. } \\
\text { (2018b) }\end{array}$ & $\begin{array}{l}30 \text { provinces of } \\
\text { China }\end{array}$ & $2006-2015$ & $\begin{array}{l}\text { Nonspatial } \\
\text { models (pooled } \\
\text { OLS, spatial FE, } \\
\text { time period } \\
\text { effects, spatial and } \\
\text { time-period } \\
\text { effects), spatial } \\
\text { Durbin model }\end{array}$ & $\begin{array}{l}\text { Environmental } \\
\text { quality index }\end{array}$ & $\begin{array}{l}\mathrm{N} \text {-shape (which } \\
\text { translates in a bell- } \\
\text { shape curve as the } \\
\text { dependent variable is } \\
\text { an indirect indicator } \\
\text { of environmental } \\
\text { degradation) }\end{array}$ & $\begin{array}{l}9500 \text { RMB per capita } \\
420,000 * \text { RMB per } \\
\text { capita } \\
\{\text { constant } 2005\}\end{array}$ \\
\hline $\begin{array}{l}\text { Joshi and Beck } \\
\text { (2018) }\end{array}$ & 87 non-OECD & $1995-2010$ & GMM & $\mathrm{CO} 2$ emissions & $\begin{array}{l}\text { Monotonically } \\
\text { increasing }\end{array}$ & - \\
\hline $\begin{array}{l}\text { Luzzati et al. } \\
\text { (2018) }\end{array}$ & $\begin{array}{l}115 \text { countries } \\
\text { (low-income } \\
\text { countries, middle- } \\
\text { income countries, } \\
\text { high-income } \\
\text { countries) }\end{array}$ & $1971-2015$ & $\begin{array}{l}\text { Semi-parametric } \\
\text { model, FGLS }\end{array}$ & $\begin{array}{l}\mathrm{CO} 2 \text { emissions, total } \\
\text { primary energy } \\
\text { supply }\end{array}$ & $\begin{array}{l}\text { Monotonically } \\
\text { increasing (low- } \\
\text { income countries; } \\
\text { CO2 emissions), U- } \\
\text { shape (low-income } \\
\text { countries; total } \\
\text { primary energy } \\
\text { supply) }\end{array}$ & $\begin{array}{l}498 \text { US\$ per capita } \\
\text { (total primary energy } \\
\text { supply) } \\
\text { \{constant } 2010\}\end{array}$ \\
\hline $\begin{array}{l}\text { Wenbo and } \\
\text { Yan (2018) }\end{array}$ & $\begin{array}{l}30 \text { provinces of } \\
\text { China }\end{array}$ & $2004-2015$ & GMM & $\begin{array}{l}\mathrm{CO} 2 \text { emissions, } \\
\mathrm{CO} 2 \text { emissions } \\
\text { intensity }\end{array}$ & Bell-shape & - \\
\hline $\begin{array}{l}\text { Leblois et al. } \\
\text { (2017) }\end{array}$ & $\begin{array}{l}128 \text { developing } \\
\text { countries }\end{array}$ & $2002-2010$ & $\mathrm{FE}$ & Deforestation rate & No statistical link & - \\
\hline $\begin{array}{l}\text { Özokcu and } \\
\text { Özdemir (2017) }\end{array}$ & $\begin{array}{l}52 \text { emerging } \\
\text { countries }\end{array}$ & $1980-2010$ & $\begin{array}{l}\text { FE, Driscoll- } \\
\text { Kraay Standard } \\
\text { Errors }\end{array}$ & $\mathrm{CO} 2$ emissions & N-shape & - \\
\hline $\begin{array}{l}\text { Sinha and } \\
\text { Bhattacharya } \\
\text { (2017) }\end{array}$ & 139 Indian cities & $2001-2013$ & $\mathrm{FE}, \mathrm{RE}$ & SO2 emissions & $\begin{array}{l}\text { Electricity model: } \\
\text { bell-shape } \\
\text { (industrial, industrial } \\
\text { high-income areas), } \\
\text { N-shape (industrial } \\
\text { low-income areas), } \\
\text { linear (residential, }\end{array}$ & $\begin{array}{l}\text { Electricity model: } \\
\text { 452.24 Rs. Lacs } \\
\text { (industrial), } \\
1110.10 \text { Rs. Lacs } \\
\text { (industrial high- } \\
\text { income), 18.87* Rs. } \\
\text { Lacs and 5604.37 Rs. }\end{array}$ \\
\hline
\end{tabular}




\begin{tabular}{|c|c|c|c|c|c|c|}
\hline & & & & & $\begin{array}{l}\text { residential low- } \\
\text { income areas) } \\
\text { Petroleum model: } \\
\text { bell-shape } \\
\text { (industrial, industrial } \\
\text { high-income areas), } \\
\text { N-shape (industrial } \\
\text { low-income areas), } \\
\text { linear (residential } \\
\text { areas), } \\
\text { monotonically } \\
\text { increasing } \\
\text { (residential low- } \\
\text { income areas), } \\
\text { monotonically } \\
\text { decreasing } \\
\text { (residential medium- } \\
\text { income areas) }\end{array}$ & $\begin{array}{l}\text { Lacs (industrial low- } \\
\text { income) } \\
\text { Petroleum model: } \\
287.52 \text { Rs. Lacs } \\
\text { (industrial), } 1564.36 \text { Rs. } \\
\text { Lacs (industrial high- } \\
\text { income), 20.51* Rs. } \\
\text { Lacs and 5799.40 Rs. } \\
\text { Lacs (industrial low- } \\
\text { income) }\end{array}$ \\
\hline $\begin{array}{l}\text { Zhang et al. } \\
\text { (2017) }\end{array}$ & $\begin{array}{l}27 \text { provinces of } \\
\text { China }\end{array}$ & $\begin{array}{l}\text { (a) } 1990- \\
2014 \\
\text { (b) } 2001- \\
2014\end{array}$ & $\begin{array}{l}\text { FE, B-spline } \\
\text { regression } \\
\text { (parametric and } \\
\text { semi-parametric } \\
\text { models), } \\
\text { cointegration } \\
\text { analysis }\end{array}$ & $\begin{array}{l}\text { (a) COD emissions } \\
\text { (b) NH3-N } \\
\text { emissions }\end{array}$ & Bell-shape & - \\
\hline $\begin{array}{l}\text { Kang et al. } \\
(2016)\end{array}$ & $\begin{array}{l}30 \text { provinces of } \\
\text { China }\end{array}$ & 1997-2012 & $\begin{array}{l}\text { Nonspatial model } \\
\text { (pooled OLS, } \\
\text { spatial FE, time- } \\
\text { period FE, spatial } \\
\text { and time-period } \\
\text { FE), spatial } \\
\text { Durbin model } \\
\text { (spatial FE, time- } \\
\text { period FE, spatial } \\
\text { and time- period } \\
\text { FE, spatial RE } \\
\text { and time }\end{array}$ & $\mathrm{CO} 2$ emissions & Inverted-N shape & $\begin{array}{l}1545.03 * \text { and } 57,308.26 \\
\text { RMB per capita } \\
\text { (nonspatial two-way FE } \\
\text { models), } 1480.30 * \text { and } \\
82,677.27 * \text { RMB per } \\
\text { capita (SDM FE } \\
\text { models) } \\
\text { \{constant } 1997 \text { \} }\end{array}$ \\
\hline Li et al. (2016) & $\begin{array}{l}28 \text { provinces of } \\
\text { China }\end{array}$ & 1996-2012 & $\begin{array}{l}\text { GMM, ARDL } \\
\text { (PMG, MG, DFE) }\end{array}$ & $\begin{array}{l}\text { CO2 emissions, } \\
\text { industrial } \\
\text { wastewater } \\
\text { emissions, industrial } \\
\text { waste solid } \\
\text { emissions }\end{array}$ & Bell-shape & $\begin{array}{l}\text { 10,403.96* US\$ per } \\
\text { capita (CO2 emissions), } \\
1063.88 \text { US } \$ \text { per capita } \\
\text { (wastewater emissions), } \\
23,076.99 * \text { US } \$ \text { per } \\
\text { capita (waste solid } \\
\text { emissions) } \\
\{\text { constant } 2012\}\end{array}$ \\
\hline $\begin{array}{l}\text { Hao et al. } \\
(2016)\end{array}$ & $\begin{array}{l}29 \text { Chinese } \\
\text { provinces }\end{array}$ & 1995-2012 & $\begin{array}{l}\text { Nonspatial panel } \\
\text { models (pooled } \\
\text { OLS, individual } \\
\text { FE, time FE, } \\
\text { individual and } \\
\text { time FE), spatial } \\
\text { Durbin models } \\
\text { (individual and } \\
\text { time FE, } \\
\text { individual and } \\
\text { time FE bias- }\end{array}$ & Coal consumption & Bell-shape & $\begin{array}{l}18,456 \text { to } 23,585 \text { yuan } \\
\text { per capita (panel } \\
\text { models), } 39,692 \text { to } \\
48,521 \text { yuan per capita } \\
\text { (spatial panel models) } \\
\text { \{constant } 1978 \text { \} }\end{array}$ \\
\hline
\end{tabular}




\begin{tabular}{|c|c|c|c|c|c|c|}
\hline & & & $\begin{array}{l}\text { corrected, random } \\
\text { individual effects, } \\
\text { fixed time effects) }\end{array}$ & & & \\
\hline $\begin{array}{l}\text { Stern and Zha } \\
\text { (2016) }\end{array}$ & 50 Chinese cities & 2013-2014 & $\mathrm{FE}$ & $\begin{array}{l}\text { PM2 } 2.5 \text { emissions, } \\
\text { PM10 emissions }\end{array}$ & U-shape & $\begin{array}{l}453,454 * \text { RMB per } \\
\text { capita (PM2.5; not } \\
\text { statistically significant), } \\
87,493 \text { RMB per capita } \\
\text { (PM10) }\end{array}$ \\
\hline $\begin{array}{l}\text { Wang et al. } \\
\text { (2016) }\end{array}$ & Chinese provinces & $1990-2012$ & $\begin{array}{l}\text { Parametric and } \\
\text { semi-parametric } \\
\text { FE }\end{array}$ & SO2 emissions & Bell-shape & - \\
\hline $\begin{array}{l}\text { Liu et al. } \\
\text { (2015) }\end{array}$ & $\begin{array}{l}31 \text { provinces of } \\
\text { China }\end{array}$ & $1997-2010$ & OLS FE & $\mathrm{CO} 2$ emissions & Inverted-N shape & $\begin{array}{l}127.41 \text { and } 10,201.29 \\
\text { yuan per capita } \\
\text { \{constant } 1997\}\end{array}$ \\
\hline $\begin{array}{l}\text { Chen and Chen } \\
\text { (2015) }\end{array}$ & $\begin{array}{l}\text { 31 Chinese } \\
\text { provinces }\end{array}$ & $1985-2010$ & $\begin{array}{l}\text { Nonparametric } \\
\text { and parametric } \\
\text { regression }\end{array}$ & $\mathrm{CO} 2$ emissions & Bell-shape & $\begin{array}{l}49,813.79 \text { yuan per } \\
\text { capita }(10.81 \text { in logs) }\end{array}$ \\
\hline $\begin{array}{l}\text { Yang et al. } \\
\text { (2015) }\end{array}$ & $\begin{array}{l}29 \text { provinces of } \\
\text { China }\end{array}$ & $1995-2010$ & $\begin{array}{l}\text { Extreme Bound } \\
\text { Analysis (General } \\
\text { Sensitivity Test), } \\
\text { bootstrapping } \\
\text { method }\end{array}$ & $\begin{array}{l}\mathrm{CO} 2 \text { emission, } \mathrm{SO} 2 \\
\text { emission, industrial } \\
\text { dust, industrial } \\
\text { waste gas, industrial } \\
\text { smoke, industrial } \\
\mathrm{SO} 2 \text { emissions, } \\
\text { industrial } \\
\text { wastewater }\end{array}$ & $\begin{array}{l}\text { Monotonically } \\
\text { increasing (CO2 } \\
\text { emissions, industrial } \\
\text { gas) }\end{array}$ & - \\
\hline Culas (2012) & $\begin{array}{l}43 \text { tropical } \\
\text { developing } \\
\text { nations (Latin } \\
\text { America, Africa, } \\
\text { Asia) }\end{array}$ & 1971-1994 & FE, RE & $\begin{array}{l}\text { Rate of } \\
\text { deforestation }\end{array}$ & $\begin{array}{l}\text { Bell-shape (Latin } \\
\text { America, Africa), } \\
\text { U-shape (Asia) }\end{array}$ & $\begin{array}{l}6072 \text { US\$ per capita } \\
\text { (Africa), } 1483 \text { US\$ per } \\
\text { capita (Latin America), } \\
2320 \text { US\$ per capita } \\
\text { (Asia) } \\
\text { constant } 1995 \text { \} }\end{array}$ \\
\hline Du et al. (2012) & $\begin{array}{l}29 \text { provinces of } \\
\text { China }\end{array}$ & $1995-2009$ & $\begin{array}{l}\text { FE, Biased- } \\
\text { corrected } \\
\text { LSDVC, GMM }\end{array}$ & $\mathrm{CO} 2$ emissions & Bell-shape & $\begin{array}{l}1.214 \mathrm{e}+15^{*} / 1.372 \mathrm{e}+14^{*} \\
/ 1.563 \mathrm{e}+14^{*} \text { yuan per } \\
\text { capita } \\
\{\text { constant } 1995\}\end{array}$ \\
\hline $\begin{array}{l}\text { Park and Lee } \\
\text { (2011) }\end{array}$ & $\begin{array}{l}16 \text { metropolitan } \\
\text { regions in } \\
\text { Republic of Korea }\end{array}$ & $1990-2005$ & FE, RE, RCM & $\begin{array}{l}\mathrm{SO} 2 \text { emissions, } \mathrm{CO} \\
\text { emissions, } \mathrm{NO} 2 \\
\text { emissions }\end{array}$ & $\begin{array}{l}\mathrm{N} \text {-shape }(\mathrm{SO} 2) \\
\mathrm{U} \text {-shape }(\mathrm{CO}, \mathrm{NO} 2)\end{array}$ & $\begin{array}{l}5700 \text { and } 28,000 \text { US\$ } \\
\text { per capita }(\mathrm{SO} 2), \\
26,400 \text { to } 30,000^{*} \text { US\$ } \\
\text { per capita }(\mathrm{CO}), 27,600 \\
\text { US\$ per capita }(\mathrm{NO} 2) \\
\text { constant } 2000 \text { \} }\end{array}$ \\
\hline
\end{tabular}

Notes: ARDL-Autoregressive Distributed Lag; ASEAN-Association of Southeast Asian Nations; CEE-Central and Eastern Europe; CCE-MG-Common Correlated Effects Mean Group; COD-Chemical Oxygen Demand; CO2-Carbon Dioxide; CUP-BC-Continuously Updated Bias Corrected; CUP-FM-Continuously Updated Fully Modified; DFE-Dynamic Fixed Efffects; DOLS-Dynamic OLS; FMOLS-Fully Modified OLS; FE-Fixed Effects; GMM-Generalized Method of Moments; MG-Mean Group; NH3-N-Discharge and Ammonia Nitrogen; NO2-Nitrogen dioxide; PMG-Pooled Mean Group; PSTR-Panel Smooth Transition Regression; RE-Random Effects; RMC-Random Coefficient Model; SAARC-South Asian Association for Regional Cooperation; SO2-Sulfur Dioxide; VAR-Vector Autoregression; VECMVector Error Correction Model; 2SLS-Two-Stage Least Squares. The "-" indicates that the turning point is not computed, while the "*" indicates that the estimated turning point is out of sample values. When both long- and short-run analysis is present, we report the pollution-growth nexus pattern and turning point associated with the long-run results. The methodology column gives information about the technique used in investigating the pollution-growth pattern, even if the respective study comprises other statistical and econometric techniques. All the information contained in the table represents our interpretation of the results in the analyzed studies. 


\subsection{Time-series analysis}

The country-specific works that tackle the relationship between growth and environmental pollution through the EKC hypothesis are listed in Table 3. At first glance, we can observe that most researchers use the ARDL bounds test approach technique to investigate the validity of the EKC hypothesis. Also, the FMOLS and DOLS techniques appear frequently as econometric tools in investigating pollution-growth pattern.

First, focusing on China, several contributions (Jalil and Feridun, 2011; Jayanthakumaran et al., 2012; Alam et al., 2016; Adebola Solarin et al., 2017; Wolde-Rufael and Idowu, 2017; Riti et al., 2017; Dong et al., 2018; and Chen et al., 2019) find empirical evidence in favor of traditional CO2 EKC hypothesis. Also, while Riti et al. (2017) estimate the peak value of the bell-shape curve within the income range values, the findings of Jalil and Feridun (2011) and Dong et al. (2018) indicate that the turning point lies outside the sample values. However, the authors cover different periods, and in particular, the three studies which compute the bell-shaped curve maxima, span the period 1978-2006 (Jalil and Feridun, 2011), 1970-2015 (Riti et al., 2017), and 1993-2016 (Dong et al., 2018). Conversely, Onafowora and Owoye (2014) conclude that the pattern between CO2 emission and growth is $\mathrm{N}$-shaped, while the associated income peak is equal to 17.050 in logs, and outside of sample values. Moreover, based on the FMOLS estimator Yao et al. (2019) reveal a monotonically increasing relationship for $\mathrm{CO} 2$ emissions. Besides, using environmental quality index (i.e. an inverse indicator of environmental pollution), the results provided by Wang et al. (2015) validate the EKC hypothesis for Gansu province in China. More specifically, the authors employ a Bayesian VAR model, and find a U-shaped pattern between the indicators for the period 1980-2012, with the estimated income threshold value of 2273 RMB per capita.

Second, for Malaysia, the empirical findings seems to cover a broad spectrum of patterns, such as the traditional bell-shaped (Saboori et al., 2012; Saboori and Sulaiman, 2013b; Lau et al., 2014; Ali et al., 2017; Azam et al., 2018), the U-shaped (Begum et al., 2015; Chandran and Tang, 2013), the inverted N-shaped (Bekhet and Othman, 2018), the monotonically increasing relationship (Azlina et al., 2014), or no statistical link (Saboori and Sulaiman, 2013a). Furthermore, Saboori et al. (2012) and Saboori and Sulaiman (2013b) unveil that the computed GDP maxima of the bell-shaped curve for the period 1980-2009 is 4700 US\$ per capita, and depending on the model 5378/5825/6003/8267 US\$ per capita, respectively. However, it is worth noting that the estimated peak value of Saboori and Sulaiman (2013b) lies outside the GDP sample 
values. As well, considering the inverted N-shaped curve, Bekhet and Othman (2018) reveal that the pollution switches its trend for a GDP value of 170.9 RM billion (trough) and 2841.9 RM billion (peak). However, the income peak lies outside the sample range values.

Third, with respect to $\mathrm{CO} 2 \mathrm{EKC}$ for Indonesia, two studies show that the bell-shaped pattern is supported by data (Alam et al., 2016; Sugiawan and Managi, 2016), while other three studies reveal mixed results, namely a monotonically increasing relationship (Yao et al., 2019; Chandran and Tang, 2013) or a U-shaped pattern (Saboori and Sulaiman, 2013a). Concerning the income threshold, Sugiawan and Managi (2016) estimate an out of sample turning point of 7729 US\$ per capita. Besides, Chandran and Tang (2013), along with Malaysia and Indonesia, examine the EKC hypothesis for Thailand, Singapore, and the Philippines, for the period 1971-2011. Overall, the empirical findings reject a long-run relationship between variables for the Philippines and Singapore, while for Thailand, the pattern seems to be convex, invalidating the EKC hypothesis. More recently, the empirical analysis of Azam et al. (2018) leads to the same conclusions, namely the presence of the U-shaped pattern for Thailand, and no statistically significant results for Singapore. Opposite, using DOLS estimator, Katircioğlu (2014) show that the EKC is valid for Singapore, for the period 1971-2010. Also, using the same sample of countries as Chandran and Tang (2013) to test the CO2 EKC hypothesis, Saboori and Sulaiman (2013a) reveal that the inverted U-shaped pattern holds only for Singapore and Thailand. The income peak value is 8.65 in logs (Singapore), and 7.47 in logs (Thailand).

Fourth, the strand of papers that target the $\mathrm{CO} 2 \mathrm{EKC}$ hypothesis for India show that in most cases the bell-shaped pattern holds (Jayanthakumaran et al., 2012; Tiwari et al., 2013; Kanjilal and Ghosh, 2013; Boutabba, 2014; Shahbaz et al., 2015; Wolde-Rufael and Idowu, 2017; Adebola Solarin et al., 2017; Sinha and Shahbaz, 2018; Yao et al., 2019), with the notable exception of Alam et al. (2016), who find that $\mathrm{CO} 2$ pollution increases along with economic growth. With regard to the turning point, authors such as Tiwari et al. (2013) and Boutabba (2014) show that its estimated value is 28,131 Indian rupees per capita for the period 1996-2011, and 19,380 Indian rupees per capita for the period 1971-2008, respectively. Also, Yao et al. (2019) find that the threshold arises for an income value of 6.61 in logs, while Sinha and Shahbaz (2018) identify an out of sample turning point which corresponds to a value of 2937.77 US\$ per capita.

Fifth, the group of scholars that focus on Tunisia, unveil both a nonlinear bell-shaped relationship between CO2 pollution and growth (Shahbaz et al., 2014; Farhani et al., 2014) and a 
U-shaped pattern (Ben Jebli and Ben Youssef, 2015). Also, for the period 1961-2004, the results of Fodha and Zaghdoud (2010) reveal an inverted U-shaped pattern for SO2 (with an associated GDP turning point value of 1200 US\$ per capita), and a monotonically increasing one for CO2.

In the case of Pakistan, Nasir and Ur Rehman (2011) and Danish et al. (2017) provide evidence that supports the EKC hypothesis for CO2 emissions, while according to Hussain et al. (2012) the pattern seems to be monotonically increasing. Moreover, according to Nasir and Ur Rehman's (2011) findings, the GDP threshold of the concave function is equal to 625 US\$ per capita. As well, the studies of Charfeddine (2017) and Mrabet and Alsamara (2017) also provide contradictory findings for Qatar. Using a Markov switching equilibrium correction model for the period 1970-2015, Charfeddine (2017) validates the EKC hypothesis for CO2 emissions and carbon ecological footprint but fails to find evidence in favor of ecological footprint EKC (i.e. the results illustrate a U-shaped pattern). Conversely, Mrabet and Alsamara (2017), employing the ARDL bounds test approach, show that the relationship between $\mathrm{CO} 2$ and growth is U-shaped, whereas, for ecological footprint, the traditional bell-shaped curve is at work.

The studies which examine the pollution-growth pattern for Turkey reveal, depending on pollution indicator, either a bell-shaped pattern (Bölük and Mert., 2015; Pata, 2018; ZambranoMonserrate et al., 2018a; Huag and Ucal, 2019), an U-shaped pattern (Huag and Ucal, 2019) or no statistical link (Huag and Ucal, 2019; Yao et al., 2019). Besides, concerning the income turning point, Bölük and Mert (2015) and Pata (2018) reveal that its estimated value lies outside the income range, and equals 9920 US\$ and 14,360 US\$ per capita, respectively. Conversely, ZambranoMonserrate et al. (2018a) and Huag and Ucal (2019) find a within-sample turning point value equals to 9031.37 US\$ and 7963.31 US\$ per capita (6385.59 US\$) for CO2 emissions (CO2 intensity), respectively.

Finally, several contributons that investigate the EKC hypothesis for other developing and transition economies unveil mixed results: (i) a monotonically increasing pattern [Al-Mulali et al. (2015) for Vietnam; Alshehry and Belloumi (2017) for Saudi Arabia; Zambrano-Monserrate et al. (2018) for Peru; Yao et al. (2019) for Russia]; (ii) a monotonically decreasing pattern [Pao et al. (2011) for Russia]; (iii) a U-shaped pattern [Ozturk and Al-Mulali (2015) for Cambodia; Halicioglu and Ketenci (2016) for Azerbaijan, Lithuania, Moldavia, Russia, and Tajikistan]; (iv) an inverted U-shaped pattern [Baek and Kim (2013) for Korea; Shahbaz et al. (2013) for Romania; Bouznit and Pablo-Romero (2016) for Algeria; Alam et al. (2016) for Brazil; Halicioglu and 
Ketenci (2016) for Armenia, Belarus, Estonia, Kyrgyzstan, Turkmenistan, and Uzbekistan; Ahmad et al. (2017) for Croatia; Pata (2018); Yao et al. (2019) for Brazil, South Africa, and South Korea]; (v) an N-shaped pattern [Onafowora and Owoye (2014) for Brazil, Egypt, Mexico, Nigeria, and South Africa]; (vi) an inverted N-shaped pattern [Onafowora and Owoye (2014) for South Korea]; (vii) and also no statistical link [Halicioglu and Ketenci (2016) for Georgia, Kazakhstan, Latvia, and Ukraine]. Likewise, Narayan and Narayan (2010), using the cointegration approach for a sample of 43 developing countries over the period 1980-2004, conclude that only in about $35 \%$ of the sample, the downward-bending curve is at work.

Furthermore, the authors who compute the associated income turning point of the specific function reveal the following results. On the one hand, Onafowora and Owoye (2014) show that the peak (i.e. 22.083 in logs) of the $\mathrm{N}$-shaped curve for Brazil lies outside the sample range, while Yao et al. (2019) unveil that the peak (i.e. 10.57 in logs) of the bell-shaped curve lies within the income sample values. On the other hand, the researchers that estimate the income peak value for South Africa reveal a similar behavior. As such, according to Onafowora and Owoye (2014), the estimated threshold (i.e. 22.963 in logs) value lies outside the sample range, while Yao et al. (2019) find the opposite (the estimated threshold equals 8.75 in logs). For Korea, Baek and Kim (2013) and Yao et al. (2019) reveal that the turning point of the bell-shaped curve lies well within the income sample values. Also, the studies which estimate the value of the income threshold for other states find values outside the sample range [Onafowora and Owoye (2014) for Egypt, Mexico, and Nigeria; Bouznit and Pablo-Romero (2016) for Algeria].

Table 3. Time-series literature survey

\begin{tabular}{|c|c|c|c|c|c|c|}
\hline Author & Sample & Year & Methodology & $\begin{array}{l}\text { Endogenous } \\
\text { variable }\end{array}$ & $\begin{array}{l}\text { Pollution-growth } \\
\text { pattern }\end{array}$ & Turning point \\
\hline Chen et al. (2019) & China & 1980-2014 & $\begin{array}{l}\text { ARDL bounds } \\
\text { test }\end{array}$ & $\mathrm{CO} 2$ emissions & Bell-shape & - \\
\hline
\end{tabular}




\begin{tabular}{|c|c|c|c|c|c|c|}
\hline Yao et al. (2019) & $\begin{array}{l}17 \text { major } \\
\text { developing } \\
\text { and developed } \\
\text { countries }\end{array}$ & $1990-2014$ & FMOLS, DOLS & $\mathrm{CO} 2$ emissions & $\begin{array}{l}\text { Bell-shape (Brazil, } \\
\text { India, South Africa, } \\
\text { South Korea }{ }^{\dagger} \text {, } \\
\text { monotonically } \\
\text { increasing (China, } \\
\text { Indonesia, Russia), no } \\
\text { statistical link (Turkey) }\end{array}$ & $\begin{array}{l}10.57 \text { in logs } \\
\text { (Brazil), } 6.61 \text { in } \\
\text { logs (India), } 8.75 \\
\text { in logs (South } \\
\text { Africa), } 9.74 \text { in } \\
\text { logs (South } \\
\text { Korea) }\end{array}$ \\
\hline Azam et al. (2018) & $\begin{array}{l}\text { Malaysia, } \\
\text { Singapore, } \\
\text { Thailand }\end{array}$ & $1990-2014$ & FMOLS & $\mathrm{CO} 2$ emissions & $\begin{array}{l}\text { Bell-shape (Malaysia), } \\
\text { U-shape (Thailand), no } \\
\text { statistical link } \\
\text { (Singapore) }\end{array}$ & - \\
\hline $\begin{array}{l}\text { Bekhet and Othman } \\
\text { (2018) }\end{array}$ & Malaysia & $1971-2015$ & $\begin{array}{l}\text { ARDL bounds } \\
\text { test, FMOLS, } \\
\text { DOLS }\end{array}$ & $\mathrm{CO} 2$ emissions & Inverted N-shape & $\begin{array}{l}170.9 \text { RM billion } \\
\text { and } 2841.9 * \mathrm{RM} \\
\text { billion } \\
\text { \{constant } 2010 \text { \} }\end{array}$ \\
\hline Dong et al. (2018) & China & 1993-2016 & $\begin{array}{l}\text { ARDL bounds } \\
\text { test, FMOLS, } \\
\text { DOLS, CCR }\end{array}$ & $\mathrm{CO} 2$ emissions & Bell-shape & $\begin{array}{l}96,680.47 * \text { yuan } \\
\text { per capita } \\
\{\text { constant } 1990\}\end{array}$ \\
\hline Pata (2018) & Turkey & 1971-2014 & $\begin{array}{l}\text { ARDL bounds } \\
\text { test }\end{array}$ & $\mathrm{CO} 2$ emissions & Bell-shape & $\begin{array}{l}14,360 * \text { US } \$ \text { per } \\
\text { capita } \\
\{\text { constant } 2010\}\end{array}$ \\
\hline $\begin{array}{l}\text { Sinha and Shahbaz } \\
(2018)\end{array}$ & India & $1971-2015$ & $\begin{array}{l}\text { ARDL bounds } \\
\text { test }\end{array}$ & $\mathrm{CO} 2$ emissions & Bell-shape & $\begin{array}{l}\text { 2937.77* US\$ per } \\
\text { capita }\end{array}$ \\
\hline $\begin{array}{l}\text { Zambrano- } \\
\text { Monserrate et al. } \\
\text { (2018a) }\end{array}$ & $\begin{array}{l}\text { France, } \\
\text { Germany, } \\
\text { Greece, } \\
\text { Portugal, } \\
\text { Turkey }\end{array}$ & 1974-2013 & $\begin{array}{l}\text { ARDL bounds } \\
\text { test }\end{array}$ & $\begin{array}{l}\text { Deforestration } \\
\text { (arable land) }\end{array}$ & Bell-shape (Turkey) & $\begin{array}{l}9,031.37 \text { US } \$ \text { per } \\
\text { capita } \\
\{\text { constant } 2010\}\end{array}$ \\
\hline $\begin{array}{l}\text { Zambrano- } \\
\text { Monserrate et al. } \\
(2018 b)\end{array}$ & Peru & 1980-2011 & $\begin{array}{l}\text { ARDL bounds } \\
\text { test }\end{array}$ & $\mathrm{CO} 2$ emissions & $\begin{array}{l}\text { Monotonically } \\
\text { increasing }\end{array}$ & - \\
\hline Ali et al. (2017) & Malaysia & $1971-2012$ & $\begin{array}{l}\text { ARDL bounds } \\
\text { test, DOLS }\end{array}$ & $\mathrm{CO} 2$ emissions & Bell-shape & - \\
\hline $\begin{array}{l}\text { Alshehry and } \\
\text { Belloumi (2017) }\end{array}$ & Saudi Arabia & 1971-2011 & $\begin{array}{l}\text { ARDL bounds } \\
\text { test }\end{array}$ & $\begin{array}{l}\text { Transport CO2 } \\
\text { emissions }\end{array}$ & $\begin{array}{l}\text { Monotonically } \\
\text { increasing }\end{array}$ & - \\
\hline Charfeddine (2017) & Qatar & $1970-2015$ & $\begin{array}{l}\text { Markov } \\
\text { switching } \\
\text { equilibrium } \\
\text { correction model }\end{array}$ & $\begin{array}{l}\mathrm{CO} 2 \text { emissions, } \\
\text { carbon ecological } \\
\text { footprint, ecological } \\
\text { footprint }\end{array}$ & $\begin{array}{l}\text { Bell-shape (CO2 } \\
\text { emissions, carbon } \\
\text { ecological footprint), } \\
\text { U-shape (ecological } \\
\text { footprint) }\end{array}$ & - \\
\hline Danish et al. (2017) & Pakistan & $1970-2012$ & $\begin{array}{l}\text { ARDL bounds } \\
\text { test, FMOLS, } \\
\text { DOLS, CCR }\end{array}$ & $\mathrm{CO} 2$ emissions & Bell-shape & - \\
\hline $\begin{array}{l}\text { Mrabet and } \\
\text { Alsamara (2017) }\end{array}$ & Qatar & 1980-2011 & $\begin{array}{l}\text { ARDL bounds } \\
\text { test }\end{array}$ & $\begin{array}{l}\mathrm{CO} 2 \text { emissions, } \\
\text { ecological footprint }\end{array}$ & $\begin{array}{l}\text { Bell-shape (ecological } \\
\text { footprint), U-shape } \\
(\mathrm{CO} 2)\end{array}$ & - \\
\hline Riti et al. (2017) & China & $1970-2015$ & $\begin{array}{l}\text { ARDL bounds } \\
\text { test, ARDL, } \\
\text { FMOLS, DOLS }\end{array}$ & $\mathrm{CO} 2$ emissions & Bell-shape & $\begin{array}{l}744,665^{*} \text { billion } \\
\text { US } \$ \text { per capita } \\
\{\text { constant } 2010\}\end{array}$ \\
\hline $\begin{array}{l}\text { Adebola Solarin et } \\
\text { al. (2017) }\end{array}$ & China, India & $1965-2013$ & $\begin{array}{l}\text { ARDL bounds } \\
\text { test }\end{array}$ & $\mathrm{CO} 2$ emissions & Bell-shape & - \\
\hline $\begin{array}{l}\text { Wolde-Rufael and } \\
\text { Idowu (2017) }\end{array}$ & China, India & $\begin{array}{l}1974-2010 \\
\text { (China), } \\
1971-2010 \\
\text { (India) }\end{array}$ & $\begin{array}{l}\text { ARDL bounds } \\
\text { test, FMOLS, } \\
\text { DOLS }\end{array}$ & $\mathrm{CO} 2$ emissions & Bell-shape & - \\
\hline
\end{tabular}




\begin{tabular}{|c|c|c|c|c|c|c|}
\hline Ahmad et al. (2017) & Croatia & $\begin{array}{l}\text { 1992Q1- } \\
\text { 2011Q1 }\end{array}$ & $\begin{array}{l}\text { ARDL bounds } \\
\text { test, FMOLS, } \\
\text { DOLS }\end{array}$ & $\mathrm{CO} 2$ emissions & Bell-shape & - \\
\hline Alam et al. (2016) & $\begin{array}{l}\text { Brazil, China, } \\
\text { India, } \\
\text { Indonesia }\end{array}$ & $1970-2012$ & $\begin{array}{l}\text { ARDL bounds } \\
\text { test }\end{array}$ & $\mathrm{CO} 2$ emissions & $\begin{array}{l}\text { Bell-shape (China, } \\
\text { Brazil, Indonesia), } \\
\text { monotonically } \\
\text { increasing (India) }\end{array}$ & - \\
\hline $\begin{array}{l}\text { Bouznit and Pablo- } \\
\text { Romero (2016) }\end{array}$ & Algeria & $1970-2010$ & $\begin{array}{l}\text { ARDL bounds } \\
\text { test }\end{array}$ & $\mathrm{CO} 2$ emissions & Bell-shape & $12.2 * / 10 *$ in logs \\
\hline $\begin{array}{l}\text { Halicioglu and } \\
\text { Ketenci (2016) }\end{array}$ & $\begin{array}{l}15 \text { transition } \\
\text { economies }\end{array}$ & 1991-2013 & $\begin{array}{l}\text { ARDL bounds } \\
\text { test, GMM }\end{array}$ & $\mathrm{CO} 2$ emissions & $\begin{array}{l}\text { Bell-shape (Armenia, } \\
\text { Belarus, Estonia, } \\
\text { Kyrgyzstan, } \\
\text { Turkmenistan, } \\
\text { Uzbekistan), U-shape } \\
\text { (Azerbaijan, Lithuania, } \\
\text { Moldavia, Russia, } \\
\text { Tajikistan), no } \\
\text { statistical link (Georgia, } \\
\text { Kazakhstan, Latvia, } \\
\text { Ukraine) }\end{array}$ & - \\
\hline $\begin{array}{l}\text { Sugiawan and } \\
\text { Managi (2016) }\end{array}$ & Indonesia & $1971-2010$ & $\begin{array}{l}\text { ARDL bounds } \\
\text { test }\end{array}$ & $\mathrm{CO} 2$ emissions & Bell-shape & $\begin{array}{l}7729 * \text { US } \$ \text { per } \\
\text { capita } \\
\{\text { constant 2005\} }\end{array}$ \\
\hline $\begin{array}{l}\text { Al-Mulali et al. } \\
\text { (2015) }\end{array}$ & Vietnam & 1981-2011 & $\begin{array}{l}\text { ARDL bounds } \\
\text { test }\end{array}$ & $\mathrm{CO} 2$ emissions & $\begin{array}{l}\text { Monotonically } \\
\text { increasing }\end{array}$ & - \\
\hline Begum et al. (2015) & Malaysia & $1970-2009$ & $\begin{array}{l}\text { ARDL bounds } \\
\text { test, DOLS, } \\
\text { Sasabuchi-Lind- } \\
\text { Mehlum U tests }\end{array}$ & $\mathrm{CO} 2$ emissions & U-shape & - \\
\hline $\begin{array}{l}\text { Bölük and Mert } \\
\text { (2015) }\end{array}$ & Turkey & $1961-2010$ & $\begin{array}{l}\text { ARDL bounds } \\
\text { test }\end{array}$ & $\mathrm{CO} 2$ emissions & Bell-shape & $\begin{array}{l}9920 * \text { US } \$ \text { per } \\
\text { capita } \\
\text { constant 2005\} }\end{array}$ \\
\hline $\begin{array}{l}\text { Ben Jebli and Ben } \\
\text { Yousseff (2015) }\end{array}$ & Tunisia & $1980-2009$ & $\begin{array}{l}\text { ARDL bounds } \\
\text { test }\end{array}$ & $\mathrm{CO} 2$ emissions & U-shape & - \\
\hline $\begin{array}{l}\text { Ozturk and Al- } \\
\text { Mulali (2015) }\end{array}$ & Cambodia & 1996-2012 & GMM, 2SLS & $\mathrm{CO} 2$ emissions & U-shape & - \\
\hline $\begin{array}{l}\text { Shahbaz et al. } \\
(2015)\end{array}$ & India & 1970-2012 & $\begin{array}{l}\text { ARDL bounds } \\
\text { test }\end{array}$ & $\mathrm{CO} 2$ emissions & Bell-shape & - \\
\hline Wang et al. (2015) & $\begin{array}{l}\text { Gansu } \\
\text { province } \\
\text { (China) }\end{array}$ & $1980-2012$ & $\begin{array}{l}\text { Bayesian VAR } \\
\text { models }\end{array}$ & $\begin{array}{l}\text { Environmental } \\
\text { quality index }\end{array}$ & $\begin{array}{l}\text { U-shape for Bayesian } \\
\text { VAR models with } \\
\text { Minnesota prior }\end{array}$ & $\begin{array}{l}2273 \text { RMB per } \\
\text { capita } \\
\text { \{constant } 1980\}\end{array}$ \\
\hline Azlina et al. (2014) & Malaysia & 1975-2011 & $\begin{array}{l}\text { Johansen } \\
\text { cointegration }\end{array}$ & $\mathrm{CO} 2$ emissions & $\begin{array}{l}\text { Monotonically } \\
\text { increasing }\end{array}$ & - \\
\hline Boutabba (2014) & India & $1971-2008$ & $\begin{array}{l}\text { ARDL bounds } \\
\text { test }\end{array}$ & $\mathrm{CO} 2$ emissions & Bell-shape & $\begin{array}{l}19,380 \text { Indian } \\
\text { rupees per capita }\end{array}$ \\
\hline Farhani et al. (2014) & Tunisia & $1971-2008$ & $\begin{array}{l}\text { ARDL bounds } \\
\text { test }\end{array}$ & $\mathrm{CO} 2$ emissions & Bell-shape & - \\
\hline Katircioğlu (2014) & Singapore & $1971-2010$ & DOLS & $\mathrm{CO} 2$ emissions & Bell-shape & - \\
\hline Lau et al. (2014) & Malaysia & $1970-2008$ & $\begin{array}{l}\text { ARDL bounds } \\
\text { test }\end{array}$ & $\mathrm{CO} 2$ emissions & Bell-shape & - \\
\hline $\begin{array}{l}\text { Onafowora and } \\
\text { Owoye (2014) }\end{array}$ & $\begin{array}{l}\text { Brazil, China, } \\
\text { Egypt, } \\
\text { Mexico, } \\
\text { Nigeria, South }\end{array}$ & $1970-2010$ & $\begin{array}{l}\text { ARDL bounds } \\
\text { test }\end{array}$ & $\mathrm{CO} 2$ emissions & $\begin{array}{l}\text { N-shape (Brazil, China, } \\
\text { Egypt, Mexico, Nigeria, } \\
\text { South Africa), } \\
\text { inverted N-shape } \\
\text { (South Korea), }\end{array}$ & $\begin{array}{l}22.083 * \text { in logs } \\
(\text { Brazil), 17.050* } \\
\text { in logs (China), } \\
16.585 * \text { in logs } \\
\text { (Egypt), 21.344* }\end{array}$ \\
\hline
\end{tabular}




\begin{tabular}{|c|c|c|c|c|c|c|}
\hline & $\begin{array}{l}\text { Africa, South } \\
\text { Korea }\end{array}$ & & & & & $\begin{array}{l}\text { in logs (Mexico), } \\
32.855^{*} \text { in logs } \\
\text { (Nigeria), 22.963* } \\
\text { in logs (South } \\
\text { Africa), } 8.071 \text { and } \\
8.746 \text { in logs } \\
\text { (South Korea) }\end{array}$ \\
\hline $\begin{array}{l}\text { Shahbaz et al. } \\
\text { (2014) }\end{array}$ & Tunisia & 1971-2010 & $\begin{array}{l}\text { ARDL bounds } \\
\text { test }\end{array}$ & CO2 emissions & Bell-shape & - \\
\hline $\begin{array}{l}\text { Baek and Kim } \\
\text { (2013) }\end{array}$ & Korea & $1978-2007$ & $\begin{array}{l}\text { ARDL bounds } \\
\text { test }\end{array}$ & CO2 emissions & Bell-shape & $\begin{array}{l}10,119 / 11,711 \\
\text { US\$ per capita, } \\
\text { \{constant 2010\} }\end{array}$ \\
\hline $\begin{array}{l}\text { Chandran and Tang } \\
\text { (2013) }\end{array}$ & $\begin{array}{l}\text { Malaysia, } \\
\text { Philippines, } \\
\text { Thailand, } \\
\text { Singapore, } \\
\text { Indonesia }\end{array}$ & 1971-2011 & $\begin{array}{l}\text { Johansen } \\
\text { cointegration }\end{array}$ & $\mathrm{CO} 2$ emissions & $\begin{array}{l}\text { U-shape (Malaysia, } \\
\text { Thailand), } \\
\text { monotonically } \\
\text { increasing (Indonesia) }\end{array}$ & - \\
\hline $\begin{array}{l}\text { Kanjilal and Ghosh } \\
\text { (2013) }\end{array}$ & India & $1971-2008$ & $\begin{array}{l}\text { Threshold } \\
\text { cointegration }\end{array}$ & $\mathrm{CO} 2$ emissions & Bell-shape & - \\
\hline $\begin{array}{l}\text { Saboori and } \\
\text { Sulaiman (2013a) }\end{array}$ & $\begin{array}{l}\text { Indonesia, } \\
\text { Malaysia, } \\
\text { Philippines, } \\
\text { Singapore, } \\
\text { Thailand }\end{array}$ & 1971-2009 & $\begin{array}{l}\text { ARDL bounds } \\
\text { test }\end{array}$ & $\mathrm{CO} 2$ emissions & $\begin{array}{l}\text { Bell-shape (Singapore, } \\
\text { Thailand), U-shape } \\
\text { (Indonesia, } \\
\text { Philippines), no } \\
\text { statistical link } \\
\text { (Malaysia) }\end{array}$ & $\begin{array}{l}8.65 \text { in logs } \\
\text { (Singapore), } 7.47 \\
\text { in logs (Thailand) }\end{array}$ \\
\hline $\begin{array}{l}\text { Saboori and } \\
\text { Sulaiman (2013b) }\end{array}$ & Malaysia & $1980-2009$ & $\begin{array}{l}\text { ARDL bounds } \\
\text { test }\end{array}$ & $\mathrm{CO} 2$ emissions & Bell-shape & $\begin{array}{l}5378 * / 6003 * / \\
8267 * / 5825 * \text { US\$ } \\
\text { per capita } \\
\{\text { constant } 2000\}\end{array}$ \\
\hline $\begin{array}{l}\text { Shahbaz et al. } \\
\text { (2013) }\end{array}$ & Romania & $1980-2010$ & $\begin{array}{l}\text { ARDL bounds } \\
\text { test }\end{array}$ & Energy emissions & Bell-shape & - \\
\hline Tiwari et al. (2013) & India & 1966-2011 & $\begin{array}{l}\text { ARDL bounds } \\
\text { test }\end{array}$ & CO2 emissions & Bell-shape & $\begin{array}{l}28,131 \text { Indian } \\
\text { rupees (531 US\$) } \\
\text { per capita }\end{array}$ \\
\hline Hussain et al. (2012) & Pakistan & 1971-2006 & $\begin{array}{l}\text { Johansen } \\
\text { cointegration }\end{array}$ & $\mathrm{CO} 2$ emissions & $\begin{array}{l}\text { Monotonically } \\
\text { increasing }\end{array}$ & - \\
\hline $\begin{array}{l}\text { Jayanthakumaran et } \\
\text { al. (2012) }\end{array}$ & China, India & $1971-2007$ & $\begin{array}{l}\text { ARDL bounds } \\
\text { test }\end{array}$ & $\mathrm{CO} 2$ emissions & Bell-shape & - \\
\hline Saboori et al. (2012) & Malaysia & $1980-2009$ & $\begin{array}{l}\text { ARDL bounds } \\
\text { test }\end{array}$ & CO2 emissions & Bell-shape & $\begin{array}{l}4700 \text { US\$ per } \\
\text { capita } \\
\{\text { constant } 2000\}\end{array}$ \\
\hline $\begin{array}{l}\text { Jalil and Feridun } \\
\text { (2011) }\end{array}$ & China & $\begin{array}{l}\text { (a) } 1953- \\
2006 \\
\text { (b) } 1978- \\
2006\end{array}$ & $\begin{array}{l}\text { ARDL bounds } \\
\text { test }\end{array}$ & CO2 emissions & Bell-shape $[(a),(b)]$ & $\begin{array}{l}\text { (b) } 11,071 * \text { to } \\
13,421 * \text { RMB per } \\
\text { capita } \\
\{\text { constant } 2000\}\end{array}$ \\
\hline $\begin{array}{l}\text { Nasir and Ur } \\
\text { Rehman (2011) }\end{array}$ & Pakistan & 1972-2008 & $\begin{array}{l}\text { Johansen } \\
\text { cointegration }\end{array}$ & $\mathrm{CO} 2$ emissions & Bell-shape & $\begin{array}{l}625 \text { US\$ per } \\
\text { capita } \\
\{\text { constant } 2000\}\end{array}$ \\
\hline Pao et al. (2011) & Russia & $1990-2007$ & $\begin{array}{l}\text { Johansen } \\
\text { cointegration }\end{array}$ & $\mathrm{CO} 2$ emissions & $\begin{array}{l}\text { Monotonically } \\
\text { decreasing }\end{array}$ & - \\
\hline $\begin{array}{l}\text { Fodha and } \\
\text { Zaghdoud (2010) }\end{array}$ & Tunisia & 1961-2004 & VAR & $\begin{array}{l}\text { SO2 emissions, } \\
\text { CO2 emissions }\end{array}$ & $\begin{array}{l}\text { Bell-shape (SO2), } \\
\text { monotonically } \\
\text { increasing }(\mathrm{CO} 2)\end{array}$ & $\begin{array}{l}1200 \text { US\$ per } \\
\text { capita ( } 3700 \text { PPP } \\
\text { US\$ per capita) } \\
\{\text { constant } 2000\}\end{array}$ \\
\hline
\end{tabular}




\begin{tabular}{|c|c|c|c|c|c|}
\hline $\begin{array}{l}\text { Narayan and } \\
\text { Narayan }(2010)\end{array}$ & $\begin{array}{l}43 \text { developing } \\
\text { states }\end{array}$ & 1980-2004 & $\begin{array}{l}\text { Cointegration } \\
\text { analysis }\end{array}$ & $\mathrm{CO} 2$ emissions & $\begin{array}{l}\text { Bell-shape (Jordan, } \\
\text { Iraq, Kuwait, Yemen, } \\
\text { Qatar, the UAE, } \\
\text { Argentina, Mexico, } \\
\text { Venezuela, Algeria, } \\
\text { Kenya, Nigeria, Congo, } \\
\text { Ghana, South Africa) }\end{array}$ \\
\hline
\end{tabular}

Notes: ARDL-Autoregressive Distributed Lag; CCR-Canonical Cointegrating Regression; CO2-Carbon Dioxide; DOLS-Dynamic OLS; FMOLS-Fully Modified OLS; FE-Fixed Effects; GMM-Generalized Method of Moments; SO2-Sulfur Dioxide; VAR-Vector Autoregression; VECM-Vector Error Correction Model; 2SLS-Two-Stage Least Squares. The "-" indicates that the turning point is not computed, while the "*" indicates that the estimated turning point is out of sample values. $\dagger$ Although South Korea was included in the developed country group, we report the associated EKC results as, in the present review, we treat it as an emerging market economy. When both long- and short-run analysis is present, we report the pollution-growth pattern and turning point associated with the longrun results. The methodology column gives information about the technique used in investigating the pollution-growth nexus pattern, even if the respective study comprises other statistical and econometric techniques. All the information contained in the table represents our interpretation of the results in the analyzed studies.

\subsection{New perspectives on modelling environmental degradation and economic growth nexus}

A large majority of the empirical studies mentioned above apply classical econometric tools to check the validity of the EKC hypothesis. However, some novel techniques, such as wavelet analysis, has recently emerged in the related literature and has gained the attention of researchers. Compared with the classical econometric techniques that are part of the time-domain and the techniques associated with the frequency-domain (e.g. the Fourier approach), the wavelet analysis is much more flexible, in the sense that covers both the time- and frequency-domain (Schleicher, 2002). Thus, this type of analysis may provide a broader perspective on data behavior by allowing to investigate different time-horizons (e.g. short-, medium-, and long-term), and highlighting the potential nonlinearities, direction of causality, and lead-lag nexus (cyclical and counter-cyclical course) between variables at distinct frequencies and time-periods (Mutascu et al., 2016).

The empirical literature regarding wavelet analysis is relatively new and limited, with almost all studies focusing on modeling the environmental degradation-economic growth nexus for developed countries (see e.g. Mutascu et al., 2016, Fosten, 2019, Raza et al., 2019, among others). Concerning developing and transition countries, authors such as Jammazi and Aloui (2015) and Kalmaz and Kirikkaleli (2019) employ wavelet techniques to examine the relationship between environmental degradation and economic growth. Nevertheless, the EKC hypothesis is explicitly tested only in the study of Jammazi and Aloiu (2015). The authors use a sample of six oil-exporting countries from the Gulf Cooperation Council (Saudi Arabia, Bahrain, Oman, United Arab Emirates, Qatar, and Kuwait), and based on wavelet windowed cross-correlation results, they show that the EKC hypothesis is valid for the period 1980-2012. More recently, Kalmaz and Kirikkaleli (2019) investigate the relationship between CO2 emissions and GDP, among other 
variables, for Turkey. According to wavelet coherence analysis, overall, the findings suggest a positive correlation between CO2 and GDP over the period 1960-2015.

Although wavelet analysis is recently adopted as a statistical tool in economics, it may represent a promising approach through which one can provide straightforward and valuable insights, and policy recommendations for different economic hypotheses such as EKC. Moreover, taking stock of the complexity of the phenomena and its interconnectedness that govern the field of energy and environmental economics, this type of approach that moves away from time-domain may add valuable information when used in empirical analysis, both solely or along with other techniques.

\section{Conclusions and policy implications}

The quality of the environment plays a vital role in nations' welfare and remains a very debatable subject both at the international and national levels. Additionally, no single formula has yet been found to fit all economic contexts in terms of mitigating pollution and its adverse effects. Starting for the premise of sustainable development, the goal of this paper was to provide both a theoretical review of the key aspects of EKC and an updated empirical review of the pollutiongrowth nexus literature that focuses on the EKC hypothesis testing in developing and transition states.

Consequently, our updated survey may provide valuable information and, to some extent, positive prospects on EKC estimation, since the reviewed works angle towards a consensus both in terms of empirical strategy and the EKC validity. On the one hand, strengthening the EKC character, most of the studies unveiled a long-term relationship between environmental pollution and economic growth. In this fashion, the findings of numerous works emphasized a cointegration relationship between variables. Thus, concerning the related techniques, the advance in statistics and econometrics has facilitated their development and implementation, all of which have had a beneficial impact on EKC estimation. On the other hand, several studies have found evidence in favor of EKC, suggesting that some developing and transition economies have succeeded in attaining the income threshold, and have improved their environmental conditions. However, according to some works, the estimated value of the income turning point lies outside the sample range. In these specific cases, the findings should be treated with care, as this may imply that the future growth may increase pollution levels, and/or highlight possible issues regarding the EKC 
and the associated threshold identification. Taken collectively, both the theoretical foundations and empirical evidence, could contribute to a better understanding of the pollution-growth nexus in the EKC context, and suggest some meaningful insights regarding the future works on the subject, as well as the crucial policy implication in developing and transition economies.

In light of the overall results, some policy implications could be drawn. First, some developing and transition states have managed to keep low levels of pollution along with economic growth, and even reached the EKC threshold for a lower level of income compared to developed nations (see e.g. the recent work of Yao et al., 2019, among others). Hence, these states could be treated as a positive example and examined more in detail to get insights related to the factors that contribute to inducing a bending downward curve in pollution. In this regard, over the years, the environmental and energy economics literature has unveiled some of the key elements that may promote a reduction in pollution levels (increase environmental quality). Focusing our attention primarily on developing and transition economies, we mention the factors related to energy structure, such as lower energy consumption, higher renewable and nuclear energy share in total energy consumption, higher energy efficiency (see e.g. Baek and Kim, 2013; Azlina, 2014; Sugiawan and Managi, 2016; Danish et al., 2017; Dong et al., 2018; Sinha and Shahbaz, 2018; Chen et al., 2019b), the factors associated to overall political system, such as good governance, corruption control, higher institutional quality, and political stability, and democracy (see e.g. Shahbaz et al., 2013; Osabuohien et al., 2014; Ozturk and Al-Mulali, 2015; Chen et la., 2018; Purcel, 2019; Ronaghi, 2019), the coexistence of an eco-friendly and relatively large industry sector and a high labor productivity which uphold complex techniques (see e.g. Lazăr et al., 2019), the environmental awareness (Chen et al., 2019a), among others. Besides, Halkos and Bampatsou (2018) revealed the importance that international agreements have on climate change mitigation. Their recent findings showed that the states which signed an international agreement, such as the Kyoto Protocol, exhibit higher environmental efficiency compared to their counterparts. These results are quite significant (all the more that their sample of 73 countries covered 55 developing ones) and may suggest that the developing world should be engaged more actively at international and also national level in green activities to ensure high environmental efficiency. Likewise, for transition economies, the findings of Zugravu-Soilita (2018) suggested that trade intensity in environmental goods reduced $\mathrm{CO} 2$ emissions, primarily through the income effect. However, the opposite is found for water pollution, while for SO2 emissions, the effect lacks significance. 
Overall, the author argued that in the context of sustainable development, freer trade in environmental goods might be attained through the regional or bilateral agreements that reflect the countries' peculiar context.

Second, after a certain threshold is reached, environmental degradation may be irreversible and costly, both economically and socially (Munasinghe, 1999). Bearing in mind that the effects of policies and regulations are often visible in the long-term, to fight against environmental degradation, it is primordial to consider all the potential detrimental factors and take preventive measures. As such, good knowledge of the domestic economic, social, and political environment, along with a constant adaptation of environmental regulations and policies, may bring added value and improve the environmental quality. Furthermore, prolific international cooperation could foster the assimilation of know-how and new green technologies. Nowadays, as also stipulated by the Paris agreement, among other instruments, there is a need for developing and transition economies to become more involved in climate change activism and fight together with developed nations against the threats of global warming. Building on the present literature review, future work could be drawn upon a meta-analysis in order to better understand the pollution-growth nexus through the EKC incidence. 


\section{References}

Adebola Solarin S, Al-Mulali U, Ozturk I (2017) Validating the environmental Kuznets curve hypothesis in India and China: The role of hydroelectricity consumption. Renewable and Sustainable Energy Reviews 80:1578-1587

Ahmad N, Du L, Lu J, Wang J, Li HZ, Hashmi, MZ (2017) Modelling the CO2 emissions and economic growth in Croatia: Is there any environmental Kuznets curve? Energy 123:164172

Al-Mulali U, Saboori B, Ozturk I (2015) Investigating the environmental Kuznets curve hypothesis in Vietnam. Energy Policy 76:123-131

Alam MM, Murad MW, Noman AHM, Ozturk I (2016) Relationships among carbon emissions, economic growth, energy consumption and population growth: testing environmental Kuznets curve hypothesis for Brazil, China, India and Indonesia. Ecological Indicators 70:466-479

Albulescu CT, Tiwari AK, Yoon S-M, Kang SH (2019) FDI, income, and environmental pollution in Latin America: Replication and extension using panel quantiles regression analysis. Energy Economics 84:104504

Ali W, Abdullah A, Azam M (2017) Re-visiting the environmental Kuznets curve hypothesis for Malaysia: Fresh evidence from ARDL bounds testing approach. Renewable and Sustainable Energy Reviews 77:990-1000

Alshehry AS, Belloumi M (2017) Study of the environmental Kuznets curve for transport carbon dioxide emissions in Saudi Arabia. Renewable and Sustainable Energy Reviews 75:13391347

Alvarado R, Ponce P, Criollo A, Córdova K, Khan MK (2018) Environmental degradation and real per capita output: New evidence at the global level grouping countries by income levels. Journal of Cleaner Production 189:13-20

Andreoni J, Levinson A (2001) The simple analytics of the environmental Kuznets curve. Journal of Public Economics 80:269-286

Awad, A (2019) Does economic integration damage or benefit the environment? Africa's experience. Energy Policy 32:991-999

Arouri MEH, Ben Youssef A, M'henni H, Rault C (2012) Energy consumption, economic growth and $\mathrm{CO} 2$ emissions in Middle East and North African countries. Energy Policy 45:342-349

Azam M, Mahmudul Alam M, Haroon Hafeez M (2018) Effect of tourism on environmental pollution: Further evidence from Malaysia, Singapore and Thailand. Journal of Cleaner Production 190:330-338

Azlina AA, Law SH, Nik Mustapha NH (2014) Dynamic linkages among transport energy consumption, income and CO2 emission in Malaysia. Energy Policy 73:598-606

Baek J, Kim HS (2013) Is economic growth good or bad for the environment? Empirical evidence from Korea Energy Economics 36:744-749 
Barra C, Zotti R (2017) Investigating the non-linearity between national income and environmental pollution: international evidence of Kuznets curve. Environmental Economics and Policy Studies 20:179-210

Basiago, AD (1999) Economic, social, and environmental sustainability in development theory and urban planning practice. The Environmentalist 19:145-161

Begum RA, Sohag K, Abdullah SMS, Jaafar M (2015) CO2 emissions, energy consumption, economic and population growth in Malaysia. Renewable and Sustainable Energy Reviews 41:594-601

Bekhet HA, Othman, NS (2018) The role of renewable energy to validate dynamic interaction between $\mathrm{CO} 2$ emissions and GDP toward sustainable development in Malaysia. Energy Economics 72:47-61

Ben Jebli M, Ben Youssef S (2015) The environmental Kuznets curve, economic growth, renewable and non-renewable energy, and trade in Tunisia. Renewable and Sustainable Energy Reviews 47:173-185

Bernard JT, Gavin M, Khalaf L, Voia M (2014) Environmental Kuznets Curve: Tipping Points, Uncertainty and Weak Identification. Environmental and Resource Economics 60:285-315

Bo S (2011) A Literature Survey on Environmental Kuznets Curve. Energy Procedia 5:1322-1325

Bölük G, Mert M (2015) The renewable energy, growth and environmental Kuznets curve in Turkey: An ARDL approach. Renewable and Sustainable Energy Reviews 52:587-595

Borghesi S (1999) The Environmental Kuznets Curve: A Survey of the Literature. FEEM Working Paper No 85-99

Boutabba MA (2014) The impact of financial development, income, energy and trade on carbon emissions: Evidence from the Indian economy. Economic Modelling 40:33-41

Bouznit M, Pablo-Romero MDP (2016) CO2 emission and economic growth in Algeria. Energy Policy 96:93-104

Brock WA, Taylor MS (2005) Economic Growth and the Environment: A Review of Theory and Empirics. Handbook of Economic Growth 1749-1821

Brock WA, Taylor MS (2010) The Green Solow model. Journal of Economic Growth 15:127-153

Bruneau JF, Echevarria C (2009) The poor are green too. Journal of International Cooperation Studies 16:1-22

Carson RT (2009) The Environmental Kuznets Curve: Seeking Empirical Regularity and Theoretical Structure. Review of Environmental Economics and Policy 4:3-23

Chandran VGR, Tang CF (2013) The impacts of transport energy consumption, foreign direct investment and income on $\mathrm{CO} 2$ emissions in ASEAN-5 economies. Renewable and Sustainable Energy Reviews 24:445-453

Charfeddine L (2017) The impact of energy consumption and economic development on Ecological Footprint and CO2 emissions: Evidence from a Markov Switching Equilibrium Correction Model. Energy Economics 65:355-374 
Charfeddine L, Mrabet Z (2017) The impact of economic development and social-political factors on ecological footprint: A panel data analysis for 15 MENA countries. Renewable and Sustainable Energy Reviews 76:138-154

Chen L, Chen S (2015) The Estimation of Environmental Kuznets Curve in China: Nonparametric Panel Approach. Computational Economics 46:405-420

Chen H, Hao Y, Li J, Song X (2018) The impact of environmental regulation, shadow economy, and corruption on environmental quality: Theory and empirical evidence from China. Journal of Cleaner Production 195:200-214

Chen X, Huang B, Lin C-T (2019a) Environmental awareness and environmental Kuznets curve. Economic Modelling 77:2-11

Chen Y, Wang Z, Zhong Z (2019b) CO2 emissions, economic growth, renewable and nonrenewable energy production and foreign trade in China. Renewable Energy 131:208-216

Chimeli AB, Braden JB (2008) A capital scarcity theory of the environmetal Kuznets curve. Environment and Development Economics 14:541-564

Chudik A, Mohaddes K, Pesaran MH, Raissi M (2016) Long-Run Effects in Large Heterogeneous Panel Data Models with Cross-Sectionally Correlated Errors. Essays in Honor of Aman Ullah. Advances in Econometrics 36:85-135

Chudik A, Pesaran MH (2015) Common correlated effects estimation of heterogeneous dynamic panel data models with weakly exogenous regressors. Journal of Econometrics 188:393420

Ciegis R, Ramanauskiene J, Martinkus B (2009) The Concept of Sustainable Development and its Use for Sustainability Scenarios. Inzinerine Ekonomika-Engineering Economics 62:28-37

Cleveland, WS (1979) Robust Locally Weighted Regression and Smoothing Scatterplots. Journal of the American Statistical Association 74:829-836

Cleveland WS (1981) LOWESS: A Program for Smoothing Scatterplots by Robust Locally Weighted Regression. The American Statistician 35:54

Cleveland WS, Devlin SJ (1988) Locally Weighted Regression: An Approach to Regression Analysis by Local Fitting. Journal of the American Statistical Association 83:596-610

Cleveland WS, Loader C (1996) Smoothing by Local Regression: Principles and Methods In: Härdle W, Schimek M G (eds) Statistical Theory and Computational Aspects of Smoothing Contributions to Statistics Physica-Verlag HD

Cole MA, Rayner AJ, Bates JM (1997) The Environmental Kuznets Curve : an empirical analysis. Environment and Development Economics 2:401-416

Culas RJ (2012) REDD and forest transition: Tunneling through the environmental Kuznets curve Ecological Economics 79:44-51

Danish, Zhang B, Wang B, Wang Z (2017) Role of renewable energy and non-renewable energy consumption on EKC: Evidence from Pakistan. Journal of Cleaner Production 156:855864

Dasgupta S, Laplante B, Wang H, Wheeler D (2002) Confronting the Environmental Kuznets Curve. The Journal of Economic Perspectives 16:147-168 
Dehghan Shabani Z, Shahnazi R (2018) Energy consumption, carbon dioxide emissions, information and communications technology, and gross domestic product in Iranian economic sectors: A panel causality analysis. Energy 169:1064-1078

Destek MA, Sarkodie SA (2019) Investigation of environmental Kuznets curve for ecological footprint: The role of energy and financial development. Science of The Total Environment 650:2483-2489

Di Vita G (2008) Is the discount rate relevant in explaining the environmental Kuznets curve? Journal of Policy Modeling 30:197-207

Dinda S (2004) Environmental Kuznets Curve Hypothesis: A Survey. Ecological Economics 49:431-455

Dinda S (2005) A theoretical basis for the environmental Kuznets curve. Ecological Economics 53:403-413

Dong K, Sun R, Jiang H, Zeng X (2018) CO2 emissions, economic growth, and the environmental Kuznets curve in China: What roles can nuclear energy and renewable energy play? Journal of Cleaner Production 196:51-63

Du L, Wei C, Cai S (2012) Economic development and carbon dioxide emissions in China: Provincial panel data analysis. China Economic Review 23:371-384

Eberhardt M, Bond S (2009) Cross-section Dependence in Non-stationary Panel Models: A Novel Estimator. MPRA Paper No. 17692

Eberhardt M, Teal F (2010) Productivity analysis in global manufacturing production. Economics Series, Working Paper 515, University of Oxford

Egli H, Steger TM (2007) A dynamic model of the environmental Kuznets curve: turning point and public policy. Environmental and Resource Economics 36:15-34

Farhani S, Chaibi A, Rault C (2014) CO2 emissions, output, energy consumption, and trade in Tunisia. Economic Modelling 38:426-434

Fodha M, Zaghdoud O (2010) Economic growth and pollutant emissions in Tunisia: An empirical analysis of the environmental Kuznets curve. Energy Policy 38:1150-1156

Fosten J 2019 CO2 Emissions and Economic Activity: a Short-to-Medium Run Perspective. Energy Economics 83:415-429

Ghalwash TM (2007) Demand for Environmental Quality: An Empirical Analysis of Consumer Behavior in Sweden. Environmental and Resource Economics 41:71-87

Grossman GM, Krueger AB (1991) Environmental Impacts of the North American Free Trade Agreement. John M. Ohlin Program Discussion Paper No. 158, Princeton Retrieved from http://www.nber.org/papers/w3914.pdf

Halkos GE, Bampatsou C (2018) Economic growth and environmental degradation: a conditional nonparametric frontier analysis. Environmental Economics and Policy Studies 21:325-347

Halicioglu F, Ketenci N (2016) The impact of international trade on environmental quality: The case of transition countries. Energy 109:1130-1138 
Hanif I, Faraz Raza SM, Gago-de-Santos P, Abbas Q (2019) Fossil fuels, foreign direct investment, and economic growth have triggered $\mathrm{CO} 2$ emissions in emerging Asian economies: Some empirical evidence. Energy 171:493-501

Hao Y, Deng Y, Lu Z-N, Chen H (2018a) Is environmental regulation effective in China? Evidence from city-level panel data. Journal of Cleaner Production 188:966-976

Hao Y, Liu Y, Weng JH, Gao Y (2016) Does the Environmental Kuznets Curve for coal consumption in China exist? New evidence from spatial econometric analysis. Energy 114:1214-1223

Hao Y, Wu Y, Wang L, Huang J (2018b) Re-examine environmental Kuznets curve in China: Spatial estimations using environmental quality index. Sustainable Cities and Society 42:498-511

Hartman R, Kwon OS (2005) Sustainable growth and the environmental Kuznets curve. Journal of Economic Dynamics and Control 29:1701-1736

Haug AA, Ucal M (2019) The Role of Trade and FDI for CO2 Emissions in Turkey: Nonlinear Relationships. Energy Economics 81:297-307

He J (2007) Is the Environmental Kuznets Curve hypothesis valid for developing countries? A Survey. Cahiers de recherche 07-03, Departement d'Economique de l'École de gestion à l'Université de Sherbrooke

Henderson DJ, Parmeter CF (2015) Applied Nonparametric Econometrics, New York, NY: Cambridge University Press

Holden E, Linnerud K, Banister D (2014) Sustainable development: Our Common Future revisited. Global Environmental Change 26:130-139

Hove S, Tursoy T (2019) An Investigation of the Environmental Kuznets Curve in Emerging Economies. Journal of Cleaner Production 236:117628

Hussain M, Irfan Javaid M, Drake PR (2012) An econometric study of carbon dioxide (CO2) emissions, energy consumption, and economic growth of Pakistan International. Journal of Energy Sector Management 6:518-533

Jalil A, Feridun M (2011) The impact of growth, energy and financial development on the environment in China: A cointegration analysis. Energy Economics 33:284-291

Jammazi R, Aloui C (2015) Environment degradation, economic growth and energy consumption nexus: A wavelet-windowed cross correlation approach. Physica A: Statistical Mechanics and Its Applications 436:110-125

Janssens-Maenhout G, Crippa M, Guizzardi D, Muntean M, Schaaf E, Olivier JGJ, Peters JAHW, Schure KM (2017) Fossil CO2 and GHG emissions of all world countries, EUR 28766 EN, Publications Office of the European Union, Luxembourg doi:10.2760/709792, JRC107877

Jayanthakumaran K, Verma R, Liu Y (2012) CO2 emissions, energy consumption, trade and income: A comparative analysis of China and India. Energy Policy 42:450-460

John A, Pecchenino R, (1994) An overlapping generations model of growth and the environment. Economic Journal 104:1393-1410 
John A, Pecchenino R, Schimmelpfennig D, Schreft S (1995) Short-lived agents and the long-lived environment. Journal of Public Economics 58:127-141

Jones LE, Manuelli RE (2001) Endogenous policy choice: the case of pollution and growth. Review of Economic Dynamics 4:369-405

Joshi P, Beck K (2018) Democracy and carbon dioxide emissions: Assessing the interactions of political and economic freedom and the environmental Kuznets curve. Energy Research and Social Science 39:46-54

Kaika D, Zervas E (2013a) The Environmental Kuznets Curve (EKC) theory-Part A: Concept, causes and the CO2 emissions case. Energy Policy 62:1392-1402

Kaika D, Zervas E (2013b) The Environmental Kuznets Curve (EKC) theory Part B: Critical issues. Energy Policy 62:1403-1411

Kalmaz DB, Kirikkaleli D (2019) Modeling CO2 emissions in an emerging market: empirical finding from ARDL-based bounds and wavelet coherence approaches. Environmental Science and Pollution Research 26:5210-5220

Kang YQ, Zhao T, Yang YY (2016) Environmental Kuznets curve for CO2 emissions in China: A spatial panel data approach. Ecological Indicators 63:231-239

Kanjilal K, Ghosh S (2013) Environmental Kuznet's curve for India: Evidence from tests for cointegration with unknown structural breaks. Energy Policy 56:509-515

Katircioğlu ST (2014) Testing the tourism-induced EKC hypothesis: The case of Singapore. Economic Modelling 41:383-391

Kijima M, Nishide K, Ohyama A (2010) Economic models for the environmental Kuznets curve: A survey. Journal of Economic Dynamics and Control 34:1187-1201

Kijima M, Nishide K, Ohyama A (2011) EKC-type transitions and environmental policy under pollutant uncertainty and cost irreversibility. Journal of Economic Dynamics and Control 35:746-763

Kim D-H, Suen Y-B, Lin SC (2019) Carbon Dioxide Emissions and Trade: Evidence from Disaggregate Trade Data. Energy Economics 78:13-28

Kuznets S (1955) Economic Growth and Income Inequality. American Economic Review 45:128

Kristrom B, Riera P (1996) Is the income elasticity of environmental improvements less than one? Environmental and Resource Economics 7:45-55

Lau LS, Choong CK, Eng YK (2014) Investigation of the environmental Kuznets curve for carbon emissions in Malaysia: Do foreign direct investment and trade matter? Energy Policy 68:490-497

Lazăr D, Minea A, Purcel AA (2019) Pollution and economic growth: Evidence from central and eastern European countries. Energy Economics 81:1121-1131

Leblois A, Damette O, Wolfersberger J (2017) What has Driven Deforestation in Developing Countries Since the 2000s? Evidence from New Remote-Sensing Data. World Development 92:82-102 
Li J, Luo Y, Wang S (2019) Spatial effects of economic performance on the carbon intensity of human well-being: The environmental Kuznets curve in Chinese provinces. Journal of Cleaner Production 233:681-694

Li T, Wang Y, Zhao D (2016) Environmental Kuznets Curve in China: New evidence from dynamic panel analysis. Energy Policy 91:138-147

Lieb CM (2002) The environmental Kuznets curve and satiation: a simple static model. Environment and Development Economics 7:429-448

Lieb CM (2003) The Environmental Kuznets Curve-A survey of the Empirical Evidence and of Possible Causes. University of Heidelberg, Department of Economics, Discussion Paper Series, no 391

Lieb CM (2004) The environmental Kuznets curve and flow versus stock pollution: the neglect of future damages. Environmental and Resource Economics 29:483-506

Lind JT, Mehlum H (2010) With or Without U? The Appropriate Test for a U-Shaped Relationship. Oxford Bulletin of Economics and Statistics 72:109-118

Liu JX, Qu JY, Zhao K (2019) Is China's development conforms to the Environmental Kuznets curve hypothesis and the pollution haven hypothesis? Journal of Cleaner Production 234:787-796

Liu Y, Yan B, Zhou Y (2015) Urbanization, economic growth, and carbon dioxide emissions in China: A panel cointegration and causality analysis. Journal of Geographical Sciences 26:131-152

Lopez R (1994) The environment as a factor of production: the effects of economic growth and trade liberalization. Journal of Environmental Economics and Management 27:163-184

Lopez, R, Mitra S (2000) Corruption, pollution, and the Kuznets environment curve. Journal of Environmental Economics and Management 40:137-150

Lucas REB, Wheeler D, Hettige H (1992) Economic development, environmental regulation, and the international migration of toxic industrial pollution: 1960-88, Policy Research Working Paper Series 1062, The World Bank

Luzzati T, Orsini M, Gucciardi G (2018) A multiscale reassessment of the Environmental Kuznets Curve for energy and CO2 emissions. Energy Policy 122:612-621

Malthus TR (1798) An Essay on the Principle of Population, as it affects the future Improvement of Society, with Remarks on the Speculations of Mr. Godwin, M. Condorcet, and Other Writers (London: J. Johnson), 1st edition

Retrieved from https://oll.libertyfund.org/titles/311

Martini C, Tiezzi S (2014) Is the environment a luxury? An empirical investigation using revealed preferences and household production. Resource and Energy Economics 37:147-167

Meadows DH, Meadows D, Randers J, Behrens III WW (1972) The Limits To Growth; a Report for the Club of Rome's Project on the Predicament of Mankind. New York :Universe Books

McConnell KE (1997) Income and the demand for environmental quality. Environment and Development Economics 2:383-399 
Millimet DL, List JA, Stengos T (2003) The Environmental Kuznets Curve: Real Progress or Misspecified Models. Review of Economics and Statistics 8594:1038-1047

Miyama E, Managi S (2014) Global environmental emissions estimate: application of multiple imputation. Environmental Economics and Policy Studies 16:115-135

Mrabet Z, Alsamara M (2017) Testing the Kuznets Curve hypothesis for Qatar: A comparison between carbon dioxide and ecological footprint. Renewable and Sustainable Energy Reviews 70:1366-1375

Munasinghe M (1999) Is environmental degradation an inevitable consequence of economic growth: tunneling through the environmental Kuznets curve. Ecological Economics 29:89109

Mutascu M, Pereau JC, Ursu E (2016) A Wavelet Analysis of the Environmental Kuznets Curve in France. Cahiers du GREThA 2016-10, Groupe de Recherche en Economie Théorique et Appliquée (GREThA)

Narayan PK, Narayan S (2010) Carbon dioxide emissions and economic growth: Panel data evidence from developing countries. Energy Policy 38:661-666

Nasir MA, Duc Huynh TL, Xuan Tram HT (2019) Role of financial development, economic growth \& foreign direct investment in driving climate change: A case of emerging ASEAN. Journal of Environmental Management 242:131-141

Nasir M, Ur Rehman F (2011) Environmental Kuznets Curve for carbon emissions in Pakistan: An empirical investigation. Energy Policy 39:1857-1864

Olivier JGJ, Janssens-Maenhout KM, Schure M, Peters JAHW (2017) Trends in global CO2 and total greenhouse gas emissions report. PBL Netherlands Environmental Assessment Agency, The Hague

Retrieved from https://www.pbl.nl/sites/default/files/cms/publicaties/pbl-2017-trends-inglobal-co2- and-total-greenhouse-gas-emissons-2017-report_2674.pdf

Omri A (2018) Entrepreneurship, sectoral outputs and environmental improvement: International evidence. Technological Forecasting and Social Change 128:46-55

Onafowora OA, Owoye O (2014) Bounds testing approach to analysis of the environment Kuznets curve hypothesis. Energy Economics 44:47-62

Ordás Criado C, Valente S, Stengos T (2011) Growth and pollution convergence: Theory and evidence. Journal of Environmental Economics and Management 62:199-214

Osabuohien ES, Efobi UR, Gitau CMW (2014) Beyond the Environmental Kuznets Curve in Africa: Evidence from Panel Cointegration. Journal of Environmental Policy and Planning 16:517-538

Ozcan B (2013) The nexus between carbon emissions, energy consumption and economic growth in Middle East countries: A panel data analysis. Energy Policy 62:1138-1147

Özokcu S, Özdemir Ö (2017) Economic growth, energy, and environmental Kuznets curve. Renewable and Sustainable Energy Reviews 72:639-647

Ozturk I, Al-Mulali U (2015) Investigating the validity of the environment Kuznets curve hypothesis in Cambodia. Ecological Indicators 57:324-330 
Panayotou T (1993) Empirical tests and policy analysis of environmental degradation at different stages of economic development, Working Paper no 238, Technology and Employment Programme, ILO, Geneva

Panayotou T (2003) Economic growth and the environment. Economic Survey of Europe 2:45-72

Pao HT, Tsai CM (2010) CO2 emissions, energy consumption and economic growth in BRIC countries. Energy Policy 38:7850-7860

Pao HT, Tsai CM (2011) Multivariate Granger causality between CO2 emissions, energy consumption, FDI (foreign direct investment) and GDP (gross domestic product): Evidence from a panel of BRIC (Brazil, Russian Federation, India, and China) countries. Energy 36:685-693

Pao HT, Yu HC, Yang YH (2011) Modeling the CO2 emissions, energy use, and economic growth in Russia. Energy 36:5094-5100

Park S, Lee Y (2011) Regional model of EKC for air pollution: Evidence from the Republic of Korea. Energy Policy 39:5840-5849

Pasten R, Figueroa BE (2012) The Environmental Kuznets Curve: A Survey of the Theoretical Literature. International Review of Environmental and Resource Economics 6:195-224

Pata UK (2018) The influence of coal and noncarbohydrate energy consumption on CO2 emissions: Revisiting the environmental Kuznets curve hypothesis for Turkey. Energy 160:1115-1123

Pearce D, Palmer C (2005) Public and private spending for environmental protection: a crosscountry policy analysis. Fiscal Studies 22:403-456

Pesaran HM (2006) Estimation and inference in large heterogeneous panels with a multifactor error structure. Econometrica 74:967-1012

Pesaran HM, Shin Y, Smith RP (1999) Pooled mean group estimation of dynamic heterogeneous panels. Journal of the American Statistical Association 94:621-634

Pesaran HM, Smith R (1995) Estimating long-run relationships from dynamic heterogeneous panels. Journal of Econometrics 68:79-113

Prieur F (2009) The environmental Kuznets curve in a world of irreversibility. Economic Theory 40:57-90

Purcel AA (2019) Does Political Stability Hinder Pollution? Evidence From Developing States. Economic Research Guardian 9:75-98

Raza SA, Shah N, Sharif A (2019) Time frequency relationship between energy consumption, economic growth and environmental degradation in the United States: Evidence from transportation sector. Energy 173:706-720

Riti JS, Song D, Shu Y, Kamah M (2017) Decoupling CO2 emission and economic growth in China: Is there consistency in estimation results in analyzing environmental Kuznets curve? Journal of Cleaner Production 166:1448-1461

Ridzuan S (2019) Inequality and the environmental Kuznets curve. Journal of Cleaner Production 228:1472-1481 
Robinson P (1983) Nonparametric estimators for time series. Journal of time series analysis 4:185207

Ronaghi M, Reed M, Saghaian S (2019) The impact of economic factors and governance on greenhouse gas emission. Environmental Economics and Policy Studies 1-20

Saboori B, Sulaiman J, Mohd S (2012) Economic growth and CO2 emissions in Malaysia: A cointegration analysis of the Environmental Kuznets Curve. Energy Policy 51:184-191

Saboori B, Sulaiman J (2013a) CO2 emissions, energy consumption and economic growth in Association of Southeast Asian Nations (ASEAN) countries: A cointegration approach. Energy 55:813-822

Saboori B, Sulaiman J (2013b) Environmental degradation, economic growth and energy consumption: evidence of the environmental Kuznets curve in Malaysia. Energy Policy 60:892-905

Sandmo A (2015) The Early History of Environmental Economics. Review of Environmental Economics and Policy 9:43-63

Schleicher C (2002) An Introduction to Wavelets for Economists. Working Paper 2002-3 Bank of Canada

Selden TM, Song D (1995) Neoclassical growth, the J curve for abatement and the inverted U curve for pollution. Journal of Environmental Economics and Management 29:162-168

Seghezzo L (2009) The five dimensions of sustainability. Environmental Politics 18:539-556

Sen S, Melenberg B, Vollebergh HRJ (2016) Identification and Estimation of the Environmental Kuznets Curve: Pairwise Differencing to Deal with Nonlinearity and Nonstationarity, CESifo Working Paper Series 5837, CESifo Group Munich

Shafik N, Bandyopadhyay S (1992) Economic growth and environmental quality: Time series and cross-country evidence Washington, DC: The World Bank, Working Paper No 904

Shahbaz M, Mutascu M, Azim P (2013) Environmental Kuznets curve in Romania and the role of energy consumption. Renewable and Sustainable Energy Reviews 18:165-173

Shahbaz M, Khraief N, Uddin GS, Ozturk I (2014) Environmental Kuznets curve in an open economy: A bounds testing and causality analysis for Tunisia. Renewable and Sustainable Energy Reviews 34:325-336

Shahbaz M, Mallick H, Mahalik MK, Loganathan N (2015) Does globalization impede environmental quality in India? Ecological Indicators 52:379-393

Shahbaz M, Sinha A (2019) Environmental Kuznets Curve for CO2 Emissions: A Literature Survey. Journal of Economic Studies 46:106-168

Sinha A, Bhattacharya J (2017) Estimation of environmental Kuznets curve for SO 2 emission: A case of Indian cities. Ecological Indicators 72:881-894

Sinha A, Shahbaz M (2018) Estimation of Environmental Kuznets Curve for CO 2 emission: Role of renewable energy generation in India. Renewable Energy 119:703-711

Solow RM (1956) A Contribution to the Theory of Economic Growth. The Quarterly Journal of Economics 70:65-94 
Stern DI (2003) The environmental Kuznets curve. Online Encyclopedia of Ecological Economics

Stern DI (2004) The Rise and Fall of the Environmental Kuznets Curve. World Development 32:1419-1439

Stern DI (2010) Between estimates of the emissions-income elasticity. Ecological Economics 69:2173-2182

Stern DI (2015) The environmental Kuznets curve after 25 years. CCEP Working Papers 1514, Centre for Climate Economics and Policy, Crawford School of Public Policy, The Australian National University

Stern DI, Common MS, Barbier EB (1996) Economic growth and environmental degradation: a critique of the environmental Kuznets curve. World Development 24:1151-1160

Stern DI, Common MS (2001) Is there an environmental Kuznets curve for sulfur? Journal of Environmental Economics and Management 41:162-178

Stern DI, Gerlagh R, Burke PJ (2017) Modeling the emissions-income relationship using long-run growth rates. Environment and Development Economics 22:699-724

Stern D, Zha D (2016) Economic growth and particulate pollution concentrations in China. Environmental Economics and Policy Studies 18:327-338

Stokey NL (1998) Are there limits to growth? International Economic Review 39:1-31

Stoddart H (2011) A pocket guide to sustainable development governance. Stakeholder Forum, Commonwealth Secretariat

Sugiawan Y, Managi S (2016) The environmental Kuznets curve in Indonesia: Exploring the potential of renewable energy. Energy Policy 98:187-198

Suri V, Chapman D (1998) Economic growth, trade and energy: implications for the environmental Kuznets curve. Ecological Economics 25:195-208

Tahvonen O, Salo S (2001) Economic growth and transitions between renewable and nonrenewable energy resources. European Economic Review 458:1379-1398

Tiba S, Omri A (2017) Literature survey on the relationships between energy, environment and economic growth. Renewable and Sustainable Energy Reviews 69:1129-1146

Tiwari AK, Shahbaz M, Hye QMA (2013) The environmental Kuznets curve and the role of coal consumption in India: co-integration and causality analysis in an open economy. Renewable and Sustainable Energy Reviews 18:519-552

Tsurumi T, Managi S (2010a) Decomposition of the environmental Kuznets curve: scale, technique, and composition effects. Environmental Economics and Policy Studies 11:1936

Tsurumi T, Managi S (2010b). Does energy substitution affect carbon dioxide emissions-income relationship? Journal of the Japanese and International Economies 24:540-551

Ulucak R, Bilgili F (2018) A reinvestigation of EKC model by ecological footprint measurement for high, middle and low income countries. Journal of Cleaner Production 188:144-157 
United Nations General Assembly (1987) Report of the world commission on environment and development: Our common future. United Nations General Assembly, Development and International Co-operation: Environment, Oslo

Retrieved from https://sustainabledevelopment.un.org/content/documents/5987ourcommon-future.pdf

Vollebergh HRJ, Melenberg B, Dijkgraaf E (2009) Identifying reduced-form relations with panel data: The case of pollution and income. Journal of Environmental Economics and Management 58:27-42

Wagner M (2008) The carbon Kuznets curve: A cloudy picture emitted by bad econometrics? Resource and Energy Economics 30:388-408

Wang L, Zhou D, Wang Y, Zha D (2015) An empirical study of the environmental Kuznets curve for environmental quality in Gangsu Province. Ecological Indicators 56:96-105

Wang Y, Han R, Kubota J (2016) Is there an Environmental Kuznets Curve for SO2 emissions? A semi-parametric panel data analysis for China. Renewable and Sustainable Energy Reviews 54:1182-1188

Waqih MAU, Bhutto NA, Ghumro NH, Kumar S, Salam MA (2019) Rising environmental degradation and impact of foreign direct investment: An empirical evidence from SAARC region. Journal of Environmental Management 243:472-480

Wenbo G, Yan C (2018) Assessing the efficiency of China's environmental regulation on carbon emissions based on Tapio decoupling models and GMM models. Energy Reports 4:713723

Wirl F (2006) Pollution thresholds under uncertainty. Environment and Development Economics 11:493-506

Wolde-Rufael Y, Idowu S (2017) Income distribution and CO2 emission: A comparative analysis for China and India. Renewable and Sustainable Energy Reviews 74:1336-1345

World Bank (2018) World Development Indicators Retrieved from https://data.worldbank.org/indicator

World Meteorogical Organization. Greenhause Gas Bulletin (2017) The state of greenhouse gases in the atmosphere based on global bbservations through 2016, No. 13, 30 October Retrieved from https://ane4bf-datap1.s3-eu-west-1.amazonaws.com/wmocms/s3fspublic/ckeditor/files/GHG_Bulletin_13 EN_final_1_1.pdf?LGJNmHpwKkEG2Qw4mE Qjdm6bWxgWAJHa

Yang H, He J, Chen S (2015) The fragility of the Environmental Kuznets Curve: Revisiting the hypothesis with Chinese data via an "Extreme Bound Analysis'". Ecological Economics 109:41-58

Yao S, Zhang S, Zhang X (2019) Renewable energy, carbon emission and economic growth: A revised environmental Kuznets Curve perspective. Journal of Cleaner Production 235:1338-1352 
Zambrano-Monserrate M., Carvajal-Lara C, Urgilés-Sanchez R, Ruano MA (2018a) Deforestation as an indicator of environmental degradation: Analysis of five European countries. Ecological Indicators 90:1-8

Zambrano-Monserrate MA, Silva-Zambrano CA, Davalos-Penafiel JL, Zambrano-Monserrate A, Ruano MA (2018b) Testing environmental Kuznets curve hypothesis in Peru: The role of renewable electricity, petroleum and dry natural gas. Renewable and Sustainable Energy Reviews 82:4170-4178

Zhang C, Wang Y, Song X, Kubota J, He Y, Tojo J, Zhu X (2017) An integrated specification for the nexus of water pollution and economic growth in China: Panel cointegration, long-run causality and environmental Kuznets curve. Science of The Total Environment 609:319328

Zhao J, Zhao Z, Zhang H (2019) The impact of growth, energy and financial development on environmental pollution in China: New evidence from a spatial econometric analysis. Energy Economics 104506

Zugravu-Soilita N (2018) The impact of trade in environmental goods on pollution: what are we learning from the transition economies' experience? Environmental Economics and Policy Studies 20:785-827 